\title{
1 Paleogene plants fractionated carbon isotopes similar to modern plants
}

3 Aaron F. Diefendorf ${ }^{a^{*}}$, Katherine H. Freeman ${ }^{\mathrm{b}}$, Scott L. Wing ${ }^{\mathrm{c}}$, Ellen D. Currano ${ }^{\mathrm{d}}$, and Kevin E. Mueller

$4 \quad{ }^{a}$ Department of Geology, University of Cincinnati, PO Box 210013, Cincinnati, OH 45221-0013 USA

$5{ }^{\mathrm{b}}$ Department of Geosciences, The Pennsylvania State University, University Park, PA 16802 USA

$6{ }^{\mathrm{c}}$ Department of Paleobiology, NHB121, P.O. Box 37012, Smithsonian Institution, Washington, DC

720013 USA

$8 \quad{ }^{\mathrm{d}}$ Department of Botany, University of Wyoming, 1000 E University Ave, Laramie, WY 82071

$9{ }^{\mathrm{e}}$ U.S. Department of Agriculture, Agricultural Research Service, Rangeland Resources Research Unit,

10 Fort Collins, CO 80526

$11{ }^{*}$ Corresponding Author. Tel. : 513-556-3787.

12 E-mail address: aaron.diefendorf@uc.edu (A. Diefendorf) 


\section{ABSTRACT}

The carbon isotope composition $\left(\delta^{13} \mathrm{C}\right)$ of terrestrial plant biomarkers, such as leaf waxes and terpenoids, provides insights into past carbon cycling. The $\delta^{13} \mathrm{C}$ values of modern plant biomarkers are known to be sensitive to climate and vegetation type, both of which influence fractionation during lipid biosynthesis by altering plant carbon supply and its biochemical allocation. It is not known if fractionation observed in living plants can be used to interpret fossil lipids because plant biochemical characteristics may have evolved during the Cenozoic in response to changes in global climate and atmospheric $\mathrm{CO}_{2}$. The goal of this study was to determine if fractionation during photosynthesis $\left(\Delta_{\text {leaf }}\right)$ in the Paleogene was consistent with expectations based on living plants. To study plant fractionation during the Paleogene, we collected samples from eight stratigraphic beds in the Bighorn Basin (Wyoming, USA) that ranged in age from 63 to $53 \mathrm{Ma}$. For each sample, we measured the $\delta^{13} \mathrm{C}$ of angiosperm biomarkers (triterpenoids and $n$-alkanes) and, abundance permitting, conifer biomarkers (diterpenoids). Leaf $\delta^{13} \mathrm{C}$ values estimated from different angiosperms biomarkers were consistently $2 \%$ lower than leaf $\delta^{13} \mathrm{C}$ values for conifers calculated from diterpenoids. This difference is consistent with observations of living conifers and angiosperms and the consistency among different biomarkers suggests ancient $\varepsilon_{\text {lipid }}$ values were similar to those in living plants. From these biomarker-based $\delta^{13} \mathrm{C}_{\text {leaf }}$ values and independent records of atmospheric $\delta^{13} \mathrm{C}$ values, we calculated $\Delta_{\text {leaf }}$. These calculated $\Delta_{\text {leaf }}$ values were then compared to $\Delta_{\text {leaf }}$ values modeled by applying the effects that precipitation and major taxonomic group in living plants have on $\Delta_{\text {leaf }}$ values. Calculated and modeled $\Delta_{\text {leaf }}$ values were offset by less than a permil. This similarity suggests that carbon fractionation in Paleogene plants changed with water availability and major taxonomic group to about the same degree it does today. Further, paleoproxy data suggest at least two of the stratigraphic beds were deposited at times when $p \mathrm{CO}_{2}$ levels were higher than today. Biomarker data from these beds are not consistent with elevated $\Delta_{\text {leaf }}$ values, possibly because plants adapted carbon uptake and assimilation characteristics to $p \mathrm{CO}_{2}$ changes over long timescales. 
39 Keywords: Paleocene, Eocene, Bighorn Basin, biomarkers, lipids, compound specific isotope analyses 


\section{Introduction}

Terrestrial plant biomarkers, and their carbon isotope ratios $\left(\delta^{13} \mathrm{C}\right)$, provide insights into ecosystems and carbon cycling from local to global scales (e.g., McInerney and Wing, 2011; Bowen, 2013). Considerable efforts have been made to constrain carbon sources, fluxes and fates, especially during periods of rapid climate change, such as hyperthermal events at the beginning of the Eocene (c.f., McInerney and Wing, 2011; Bowen, 2013). Carbon isotope excursions (CIEs) during critical time intervals, such as during the Paleocene-Eocene Thermal Maximum, provide similar records of CIE shape and direction at different sites, but the CIE magnitude and shape differ, causing uncertainty in the size and timing of the carbon perturbation. This disagreement among records has led to questions about the degree to which local records of $\delta^{13} \mathrm{C}$ record shifts in the isotopic composition of the atmosphere (e.g., McInerney and Wing, 2011). It also implies plant $\delta^{13} \mathrm{C}$ records have variable sensitivities to changing climate and plant communities (Diefendorf et al., 2010).

Changes in the $\delta^{13} \mathrm{C}$ of terrestrial organic matter (and especially plant biomarkers) through geologic time are often used as proxies for atmospheric $\delta^{13} \mathrm{C}$, because having been fixed from atmospheric $\mathrm{CO}_{2}$ through photosynthesis, plant carbon should reflect the $\delta^{13} \mathrm{C}$ of the atmosphere. This process assumes that the many sources of fractionation between atmosphere and plant are constant or can be corrected for (Diefendorf et al., 2010; Freeman et al., 2011; Cernusak et al., 2013). During carbon fixation, atmospheric $\mathrm{CO}_{2}$ is converted to sugars by the enzyme Rubisco, which fractionates strongly against ${ }^{13} \mathrm{C}$; this enzymatic discrimination, along with other factors (diffusion, mesophyll and stomatal conductance), results in a large net isotope effect (e.g., Farquhar et al., 1989). Fractionation during photosynthesis $\left(\Delta_{\text {leaf }}\right)$, also referred to as carbon isotope discrimination, is quantified as

$$
\left.\Delta_{\text {leaf }}=\frac{\delta^{13} C_{\text {atm }}-\delta^{13} C_{\text {leaf }}}{1+\left(\delta^{13} C_{\text {leaf }} / 1000\right)} \quad \text { Eq. } 1\right)
$$


Theoretical and empirical studies show that fractionation during carbon assimilation and fixation is sensitive to many factors including water availability, major taxonomic group, light intensity, photosynthetic pathway, and carbon dioxide partial pressure (Farquhar et al., 1989; Diefendorf et al., 2010; Schubert and Jahren, 2012; Cernusak et al., 2013; Graham et al., 2014).

For studies using lipid biomarkers, carbon isotope fractionation during biomarker synthesis is also important (Fig. 1a), but it is less constrained than photosynthetic fractionation. Isotope fractionation occurs during biochemical reactions and the net fractionation is a function of carbon source, the availability of the reactant, and down-stream reactions that influence fractionation (Hayes, 2001).

76 Fractionation during biosynthesis $\left(\varepsilon_{\text {lipid }}\right)$ is quantified by:

$$
\varepsilon_{\text {lipid }}=\left(\frac{\delta^{13} C_{\text {lipid }}+1000}{\delta^{13} C_{\text {leaf }}+1000}-1\right) \times 10^{3} \approx\left(\delta^{13} C_{\text {lipid }}-\delta^{13} C_{\text {leaf }}\right)
$$

The purpose of this study was to improve our ability to interpret past changes in carbon isotope composition of land plant biomarkers by establishing if $\Delta_{\text {leaf }}$ was different during the Paleogene when

82 climate and atmospheric conditions deviated, sometimes greatly, from modern conditions. To accomplish our goal, we focused on sediments collected from the Paleocene (63 Ma) to early Eocene (53 Ma) from the Bighorn Basin (Wyoming, USA). This area was chosen because of the detailed climate and floral information that has been the focus of many studies. Samples were collected from eight stratigraphic beds, with multiple horizons sampled from within beds, yielding fifteen horizons. A companion study focused on terpenoid biomarkers as fossil vegetation proxies (Diefendorf et al., 2014). We measured $\delta^{13} \mathrm{C}$ values of leaf wax $n$-alkanes, one of the most commonly used biomarkers, and di- and triterpenoids that are specific to conifers and angiosperms, respectively, from the same rocks samples. Although terpenoid compounds are not as well preserved as $n$-alkanes (Diefendorf et al., 2014), they provide unaltered taxon-

91 specific $\delta^{13} \mathrm{C}$ values (Freeman et al., 1994). We measured them in this study to compare conifers and 
92 angiosperms, which are known to have different $\Delta_{\text {leaf }}$ values when grown under similar conditions (see

93 Diefendorf et al, 2010; 2011 and references therein).

95 We calculated $\Delta_{\text {leaf }}$ values from the $\delta^{13} \mathrm{C}$ values of individual plant biomarkers ( $\Delta_{\text {leaf-lipid }}$ Fig. 1b), after 96 correcting for biosynthetic fractionation, and from estimates of $\delta^{13} \mathrm{C}_{\mathrm{atm}}$ based on benthic foraminifera

97 (Tipple et al., 2010). These calculated $\Delta_{\text {leaf-lipid }}$ values were then compared to estimated, or "modeled",

$98 \Delta_{\text {leaf }}$ values that were determined using two approaches (Fig. 1b). The first approach, denoted as $\Delta_{\text {leaf-MAP, }}$

99 models $\Delta_{\text {leaf }}$ values as a function of the potential effects of precipitation on $\Delta_{\text {leaf }}$, following a meta-analysis

100 of $\Delta_{\text {leaf }}$ values from 334 living woody plant species that also accounts for effects of major taxonomic

101 group on $\Delta_{\text {leaf }}$ (i.e. it considered angiosperms and gymnosperms separately; Diefendorf et al., 2010). The

102 second approach, denoted as $\Delta_{\text {leaf- } p \mathrm{CO} 2}$, models $\Delta_{\text {leaf }}$ values as a function of atmospheric $p \mathrm{CO}_{2}$ on $\Delta_{\text {leaf, }}$

103 following a study of two living plant species described by Schubert and Jahren (2012). To determine if

$104 \Delta_{\text {leaf }}$ variability during the Paleogene is consistent with the effects of environmental conditions and plant

105 phylogeny on $\Delta_{\text {leaf }}$ of living plants, we then compared calculated and modeled $\Delta_{\text {leaf }}$ values. We conclude

106 that Paleogene plants are likely to have had similar $\Delta_{\text {leaf }}$ to living plants, and that including the effect of

107 precipitation and taxonomic group increases the correspondence between Paleogene $\Delta_{\text {leaf }}$ and modern

$108 \Delta_{\text {leaf }}$ We do not find evidence that $\Delta_{\text {leaf }}$ is influenced by $p \mathrm{CO}_{2}$ during the Paleogene.

\section{Sample locations and methods}

\section{$111 \quad 2.1$. Geological and sedimentological setting}

113 Samples were collected from outcrops of the Paleocene Fort Union and lower Eocene Willwood

114 Formations in the Bighorn Basin, Wyoming, USA (Figure 2). The Bighorn Basin is a Laramide structural

115 depression surrounded by mountains uplifted during the Paleocene and early Eocene (Bown, 1980).

116 Common lithologies include fluvial sandstones, mudstones, minor lignites and carbonaceous shales (i.e. 
117 organic carbon rich). Fort Union sediments are primarily gray-brown colored with interspersed lignitic 118 and carbonaceous shales (Bown, 1980). The Willwood Formation is dominated by oxidized mudstone

119 paleosols that are variegated red, purple, and yellow, but there are also channel sandstones, laterally

120 extensive carbonaceous shales and abandoned channel deposits containing plant fossils and dispersed

121 organic material (e.g., Davies-Vollum and Wing, 1998). The paleoelevation of the Bighorn Basin during

122 the Paleogene was likely $<1$ km (Wing and Greenwood, 1993; McMillan et al., 2006).

124 The age of each bed was calculated by linear interpolation between levels of known age and stratigraphic 125 position within each section (Wing et al., 2000; Wing and Currano, 2013). Each sampled stratigraphic

126 level is a laterally continuous (ca. 0.5 to $18 \mathrm{~km}$ ) carbonaceous bed. These carbonaceous beds represent 127 deposition on wet distal floodplains where organic matter $(\mathrm{OM})$ was preserved because of a high water 128 table, reducing conditions in the sediment and frequent depositional events. Individual carbonaceous beds 129 are thought to represent deposition over a period of centuries to a few millennia (Davies-Vollum and 130 Wing, 1998). Bed descriptions, age determination, and flora are reported in Diefendorf et al. (2014).

132 Within each carbonaceous bed, samples were collected from five sites spaced at intervals of hundreds of 133 meters along the outcrop, and at each site one to three different lithologies (horizons) were collected from 134 unweathered rock dug from a short vertical section through the bed (Table 1). For each sample, we 135 measured the proportion (wt. \%) of total organic carbon (TOC) and the carbon isotope value of TOC $136\left(\delta^{13} \mathrm{C}_{\text {TOC }} ; \mathrm{n}=75\right)$. A subset of samples was selected for biomarker analysis $(\mathrm{n}=43)$.

\subsection{Extraction and separation}

139 Samples for extraction were rinsed with dichloromethane (DCM), broken into ca. 1-cm pieces, oven-dried 140 and powdered in a ball mill. Powdered samples (25-120 g) were extracted by Soxhlet with

$141 \mathrm{DCM} /$ methanol $(9: 1, \mathrm{v} / \mathrm{v})$ for $24 \mathrm{~h}$. The total lipid extract was purified via asphaltene precipitation and 142 separated into apolar and polar fractions on silica gel with hexanes/DCM (9:1, v/v) and DCM/MeOH 
143 (1:1), respectively. The apolar fraction was further separated into saturated and unsaturated fractions on

$1445 \%$ Ag-impregnated silica gel $(\mathrm{w} / \mathrm{w})$ with hexanes and ethyl acetate, respectively.

\subsection{Identification and quantification}

147 Lipids were assigned using gas chromatography-mass spectrometry (GC-MS) with a Hewlett-Packard 148 (HP) $6890 \mathrm{GC}$ instrument coupled to a HP 5973 quadrupole MS with electron ionization. A fused silica 149 column (Agilent J\&W DB-5; $30 \mathrm{~m}, 0.25 \mathrm{~mm}, 25 \mu \mathrm{m}$ ) was used. A split/splitless injector was operated in 150 pulsed splitless mode at $320^{\circ} \mathrm{C}$ with a column flow of $1.5 \mathrm{ml} / \mathrm{min}$. The temperature program was: $60{ }^{\circ} \mathrm{C}$ 151 (1 min) to $140{ }^{\circ} \mathrm{C}$ at $15^{\circ} \mathrm{C} / \mathrm{min}$, then to $320^{\circ} \mathrm{C}$ (held $20 \mathrm{~min}$ ) at $4{ }^{\circ} \mathrm{C} / \mathrm{min}$.

\subsection{Bulk carbon isotope analyses}

$154 \delta^{13} \mathrm{C}$ of bulk organic carbon and weight percent total organic carbon (wt. \% TOC) were determined via 155 continuous flow $(\mathrm{He} ; 120 \mathrm{ml} / \mathrm{min})$ on a Costech elemental analyzer (EA) coupled to a Thermo Finnegan 156 Delta Plus XP IRMS. $\delta^{13} \mathrm{C}$ values were corrected for sample size dependency and then normalized to the

157 VPDB scale using a two-point calibration. Error was determined by analyzing additional independent 158 standards measured in all EA runs. Long-term accuracy of all EA runs was $\pm 0.01 \%(n=116)$ and 159 precision was $\pm 0.12 \%(\mathrm{n}=170 ; 1 \sigma)$.

\subsection{Compound-specific carbon isotope analyses}

162 Saturated and unsaturated hydrocarbon fractions were analyzed on a Varian model $3400 \mathrm{GC}$ coupled to a 163 Finnegan Mat 252 IRMS. Isotopic abundances were determined relative to a reference gas calibrated with 164 Mix A ( $n$ - $\mathrm{C}_{16}$ to $n$ - $\mathrm{C}_{30}$ alkanes; Arndt Schimmelmann; Indiana University). Within run precision and 165 accuracy was determined with co-injected internal standards and are $0.18 \%$ o $(1 \sigma, \mathrm{n}=153)$ and $-0.08 \%$ (n $=$ 166 153), respectively. Mix A was analyzed daily to verify long-term stability of the reference gas calibration. 
170 values were determined using the Monte Carlo method (Anderson, 1976) with 3000 iterations. This was

171 sufficient replication for the Monte Carlo standard error of the mean to be less than $0.1 \%$. Input

172 uncertainties were considered for $\delta^{13} \mathrm{C}_{\text {atm }}$ and $p \mathrm{CO}_{2}$, mean annual precipitation (MAP), $\delta^{13} \mathrm{C}$ values of $n$ -

173 alkanes and terpenoids, lipid biosynthetic fractionation $\left(\varepsilon_{\text {lipid }}\right)$, and uncertainties in $\Delta_{\text {leaf }}$ models from

174 Diefendorf et al. (2010).

175

\section{Results}

\subsection{Description and organic geochemistry of sediments}

All sediments were deposited in wet floodplain environments, but variations in grain size, TOC and sedimentary features indicate a range of sub-habitats (Wing, 1984). Local heterogeneity in the composition of leaf fossil assemblages along each bed indicates variability in the ancient vegetation

182 (Davies-Vollum and Wing, 1998), and this variability is also observed in the spatial distributions of 183 biomarkers. Biomass estimates from leaf assemblages are dominated by angiosperms ( $85-95 \%$ of the total 184 flora; see Diefendorf et al., 2014).

The $n$-alkane concentrations were highest for long-chain $n$-alkanes (e.g. $\mathrm{C}_{27}$ to $\mathrm{C}_{33}$ ) derived from vascular

187 plant leaf wax (Fig. 3). The most abundant was $n-\mathrm{C}_{29}$ with a concentration ranging from 0 to $285 \mu \mathrm{g} / \mathrm{g} \mathrm{C}$

188 (mean $54 \mu \mathrm{g} / \mathrm{g} \mathrm{C}$ ). Long-chain $n$-alkane abundances were highest for samples from Fifteenmile Creek and

189 the Latest Paleocene. Mid-chain $n$-alkanes, produced in relatively large quantities by submerged and

190 floating aquatic plants, were typically lower in abundance (mean of $15 \mu \mathrm{g} / \mathrm{g} \mathrm{C}$ ) than long-chain $n$-alkanes.

191 Short-chain $n$-alkanes, typical of algae $\left(\mathrm{C}_{15}, \mathrm{C}_{17}, \mathrm{C}_{19}\right)$, had the lowest abundance $(5 \mu \mathrm{g} / \mathrm{g} \mathrm{C})$. The higher

192 abundance of longer chain $n$-alkanes is typical of terrestrial sediments, where the dominant source of $n$ -

193 alkanes is higher plants, with a minor contribution from aquatic sources (Diefendorf et al., 2014).

194 Sediment lithologies sampled in this study (shales, lignites and mudstones) are typical of overbank facies 
196 varied. This is supported by variable abundances of short-chain $n$-alkanes in the sediments (Diefendorf et 197 al., 2014). The $n$-alkane average chain length (ACL) ranged between 27.4 and 29.3 (Diefendorf et al., 198 2014) and is within the range commonly observed for modern tree species (Diefendorf et al., 2011; Bush 199 and McInerney, 2013).

Plant-derived terpenoids were present in all but one of the samples (Fig. 3). Conifer-derived tricyclic

202 diterpenoids were found in the saturated and unsaturated hydrocarbon fractions with the most abundant

203 diterpenoids in the pimarane and abietane classes. Angiosperm-derived pentacyclic triterpenoids were 204 also abundant (Diefendorf et al., 2014).

\subsection{Bulk carbon isotopes}

$207 \delta^{13} \mathrm{C}_{\text {Tос }}$ values range from -23.5 to $-28.2 \%$ (Table 2 and A-1, Fig. 4). Within each stratigraphic horizon, $208 \delta^{13} \mathrm{C}_{\mathrm{TOC}}$ ranges were smaller, but still highly variable. For example, $\delta^{13} \mathrm{C}_{\mathrm{TOC}}$ values in lignitic shales 209 varied from -23.5 to $-26.2 \%$ at Cf-1 and from -25.6 to $-27.7 \%$ at the Honeycombs. Standard deviations of

$210 \delta^{13} \mathrm{C}_{\mathrm{TOC}}$ values within each stratigraphic horizon range from 0.2 to $1.1 \%$ (Table 2 ). Weight $\%$ TOC varied 211 from 0.1 to $55.9 \%$. Contrary to previous studies of these formations (Wing et al., 2005), no correlation 212 was observed between weight $\%$ TOC and $\delta^{13} \mathrm{C}_{\mathrm{TOC}}\left(R^{2}=0.02, p=0.19\right)$, even if only samples with $<4 \%$ 213 TOC were considered.

\section{3.3. Compound-specific carbon isotopes}

216 Carbon isotope values of long-chain $n$-alkanes (Fig. 4, Table 3 and A-1) are slightly different between 217 chain lengths. For the $n-\mathrm{C}_{29}$ alkane, values ranged between $-32.9 \%$ at Grimy Gulch to $-28.9 \%$ at the Belt 218 Ash. Values typically ranged c. 1.7\%o for multiple samples collected from the same stratigraphic bed with 219 standard deviations ranging from 0.3 to $1.0 \%$. $\delta^{13} \mathrm{C}$ values of tricyclic diterpenoids ranged from $-30.0 \%$ 
at the Latest Paleocene to $-21.9 \%$ at the Belt Ash. Dehydroabietane, a common terpenoid found in

221 geologic samples and the most common diterpenoid in this study, ranged from -25.9 to $-20.3 \%$.

222 Triterpenoid $\delta^{13} \mathrm{C}$ values ranged from -28.8 to -25.8\%o. The most common triterpenoids, 2,2,4a,9-

223 tetramethyl-1,2,3,4,4a,5,6,14b-octahydropicene and des-A-lupane, ranged from -28.9 to $-24.6 \%$ and -28.3

224 to $-25.6 \%$, respectively. Diterpenoids were $1.7 \%$ higher than triterpenoids $(\mathrm{n}=14$, paired $t$-test, $p=0.02)$

225 measured in the same samples. Compared to $n-\mathrm{C}_{29}$ alkane as measured in the same samples, diterpenoids

226 were 6.0\% higher $(\mathrm{n}=25$, Wilcoxon Signed Rank, $p<0.0001)$ and triterpenoids were $4.1 \%$ higher $(\mathrm{n}=$

227 21, paired $t$-test, $p<0.0001)$. These comparisons of $\delta^{13} \mathrm{C}$ values of terpenoids and $n$-alkanes do not take

228 into account differences in biosynthetic fractionation at this level (see below).

\subsection{Paleogene leaf $\delta^{13} \mathrm{C}$ values}

231 Lipid $\delta^{13} \mathrm{C}$ values were converted to leaf $\delta^{13} \mathrm{C}$ values $\left(\delta^{13} \mathrm{C}_{\text {leaf }}\right)$ using a correction for the net fractionation

232 during lipid biosynthesis $\left(\varepsilon_{\text {lipid }}\right)$. Both the biochemical pathways and their characteristic $\varepsilon_{\text {lipid }}$ values vary

233 by lipid class. In the case of $n$-alkanes, fractionation occurs during the conversion of pyruvate to acetyl-

234 CoA to yield $n$-alkanoic acids of intermediate length, which are subsequently elongated, and then

235 decarboxylated to $n$-alkanes (Kolattukudy et al., 1976). Based on analyses of modern angiosperm trees in

236 the temperate zone, $\varepsilon_{\text {lipid }}$ values for $n$-alkanes average $-4.6 \%$ o $( \pm 2.2,1 \sigma)$ and $-5.0 \%$ o $( \pm 2.2,1 \sigma)$ for $n$ - $\mathrm{C}_{29}$

237 and $n-\mathrm{C}_{31}$, respectively (Diefendorf et al., 2011), but see Discussion Section 4.1.

239 Terpenoids biosynthesis, which can take place by several pathways, characteristically differs among plant

240 types. Conifers synthesize diterpenoids by the 2-C-methyl-D-erythritol-4-phosphate (MEP) pathway,

241 while angiosperms synthesize triterpenoids by the mevalonic acid (MVA) pathway. Although

242 environmental, functional and taxonomic controls on terpenoid biosynthetic fractionation are not known,

$243 \varepsilon_{\text {lipid }}$ values observed in living plants are much smaller for both types of terpenoids relative to $n$-alkanes.

244 For the species studied thus far, including conifers and angiosperm tree species from the temperate zone, 
$\varepsilon_{\text {lipid }}$ values are $-0.6 \%$ o $( \pm 1.8,1 \sigma)$ and $-0.4 \%$ o $( \pm 1.2,1 \sigma)$ for diterpenoids and triterpenoids, respectively

246 (Diefendorf et al., 2012).

Leaf $\delta^{13} \mathrm{C}$ values were calculated using $\varepsilon_{\text {lipid }}$ values reported above (Table 4) and Equation $2 . \delta^{13} \mathrm{C}_{\text {leaf }}$

249 values were similar, despite being calculated separately from $n-\mathrm{C}_{29}$ alkanes and triterpenoids $(\mathrm{n}=25$,

250 paired $t$-test). This similarity is notable, and is consistent with previous work that suggests the $n$-alkanes

251 are primarily derived from angiosperms (Diefendorf et al., 2011; Bush and McInerney, 2013). In contrast,

$252 \quad \delta^{13} \mathrm{C}_{\text {leaf }}$ calculated from $n-\mathrm{C}_{29}$ alkane and diterpenoids differed by $2.1 \%$ o $(\mathrm{n}=25$, Wilcoxon Signed Rank, $p$

$253<0.001)$, and were similarly different between di- and triterpenoids $(1.9 \%, \mathrm{n}=14$, Wilcoxon Signed

254 Rank, $p=0.04)$. These differences in $\delta^{13} \mathrm{C}_{\text {leaf }}$ are consistent with differences observed between

255 angiosperms and conifers currently living at sites with similar climate (Diefendorf et al., 2010). Leaf $\delta^{13} \mathrm{C}$

256 values calculated from $n-\mathrm{C}_{29}$ alkanes correlated with bulk $\delta^{13} \mathrm{C}$ values when averaged at the site level and

257 the Grimy Gulch site is removed $\left(\mathrm{R}^{2}=0.58, p=0.046\right)$.

\subsection{Leaf fractionation in the past}

$260 \Delta_{\text {leaf }}$ values were calculated using Equation 1 with $\delta^{13} \mathrm{C}_{\text {leaf }}$ values (determined as noted above from lipids; $261 \Delta_{\text {leaf-lipid }}$ ) and $\delta^{13} \mathrm{C}_{\text {atm }}$ values reconstructed by Tipple et al. (2010). Tipple et al. (2010) calculated $\delta^{13} \mathrm{C}_{\mathrm{atm}}$ 262 values using planktonic and benthic foraminifera $\delta^{13} \mathrm{C}$ and $\delta^{18} \mathrm{O}$ records, corrected for temperature263 sensitive equilibrium and non-equilibrium isotope effects between carbonate minerals and atmospheric $264 \mathrm{CO}_{2}$. Following the suggestions of Tipple et al., in this study, $\delta^{13} \mathrm{C}_{\text {atm }}$ values from benthic foraminifera 265 were averaged using a 3 million year window. Total uncertainty in the calculated $\Delta_{\text {leaf-lipid }}$ values was 266 determined for each stratigraphic bed using the Monte Carlo method (Anderson, 1976). This approach 267 employs the standard deviations in $\delta^{13} \mathrm{C}$ values of the lipids measured within a stratigraphic bed, the 268 uncertainty in $\varepsilon_{\text {lipid, }}$, and the uncertainty in $\delta^{13} \mathrm{C}_{\text {atm }}$ values (reported in Tipple et al., 2010), and provides an estimate of their combined influence on net uncertainty using a resampling model. $\Delta_{\text {leaf-lipid }}$ values and 
associated uncertainty are presented in Table 5 and Figure 5 with $\Delta_{\text {leaf }}$ values split by taxonomic group with the assumption that all $n$-alkanes are from angiosperms (Diefendorf et al., 2011).

For $n-\mathrm{C}_{29}$ alkane, calculated $\Delta_{\text {leaf-lipid }}$ values ranged between 21.2\%o at Dorsey Creek Fence and 23.1\%o at

274 the Honeycombs. Uncertainties in $\Delta_{\text {leaf-lipid }}$ ranged from 2.3 to $2.6 \%$ ( $\left.1 \sigma\right)$. A one-at-a-time sensitivity 275 analysis was performed to determine the greatest source of uncertainty from $n-\mathrm{C}_{29}$ alkane. The $\varepsilon_{\text {lipid }}$ 276 uncertainty explained the greatest amount of the total uncertainty $(\sim 75 \%)$ in the Monte Carlo analysis.

277 The remaining uncertainty was split between $\delta^{13} \mathrm{C}_{\text {atm }}$ and the $\delta^{13} \mathrm{C} n$-alkanes. $\Delta_{\text {leaf-lipid }}$ values from $n$-C $\mathrm{C}_{31}$ 278 alkanes and triterpenoids were very similar. However, the uncertainty from the triterpenoids was smaller

$279(1.3$ to $1.8 \%$ o $)$ and this can be attributed to the smaller uncertainty in triterpenoid $\varepsilon_{\text {lipid }}$ values. The $\Delta_{\text {leaf-lipid }}$ 280 values for the conifer diterpenoids were lower than $\Delta_{\text {leaf-lipid }}$ values calculated for the angiosperms, with 281 the exception of the Latest Paleocene Honeycombs bed, which has a $\Delta_{\text {leaf-lipid }}$ value of $25.2 \%$. The mean 282 diterpenoid $\delta^{13} \mathrm{C}$ values for each sample at this site are several \%o more negative than any other 283 stratigraphic bed (Table 3, Fig. 4). More negative $\delta^{13} \mathrm{C}$ values were measured in almost all of the tricyclic 284 diterpanes and diterpenes in each of the samples. Interestingly, $n$-alkanes and triterpenoids do not have these negative $\delta^{13} \mathrm{C}$ values and are very similar to the beds above and below the Latest Paleocene.

\subsection{Leaf fractionation in the past based on modern plants and their sensitivity to water and $p \mathrm{CO}_{2}$}

288 Leaf fractionation was modeled using $\Delta_{\text {leaf }}$ estimates generated for a meta-analysis of leaf $\delta^{13} \mathrm{C}$ and MAP 289 in living plants (Diefendorf et al., 2010). This modeled $\Delta_{\text {leaf }}\left(\Delta_{\text {leaf-MAP }}\right)$ is compared to lipid-based $\Delta_{\text {leaf }}$ 290 values below. As reported by these and many other authors, $\Delta_{\text {leaf }}$ values strongly correlate with mean 291 annual precipitation, with the responses of angiosperms' and conifers' $\Delta_{\text {leaf }}$ values offset by about $2.7 \%$ 292 (Diefendorf et al., 2010). Thus we used relationships between $\Delta_{\text {leaf }}$ and water availability for the two 293 major plant types (Eqs. 3, 4; Diefendorf et al. 2010 and discussion therein) to reconstruct predicted values 294 for $\Delta_{\text {leaf-MAP }}$ using proxy-based MAP estimates for each of the Paleogene sites. 
Angiosperm modeled $\Delta_{\text {leaf-MAP }}=3.14( \pm 0.39) X \log _{10}(\mathrm{MAP})+11.58( \pm 1.23) \quad$ (Eq. 3$)$

$$
\text { Conifer modeled } \Delta_{\text {leaf-MAP }}=5.38( \pm 0.76) X \log _{10}(\mathrm{MAP})+3.16( \pm 2.18) \quad(\text { Eq. } 4)
$$

Paleogene MAP values were determined from leaf-area analysis of specimens collected by Currano et al. $(2008 ; 2010)$ (Table 1). This approach is based on the observation that MAP correlates to the mean natural logarithm of leaf-areas of woody dicotyledon species (Wilf et al., 1998). Paleogene Bighorn Basin

303 MAP values ranged from 109 to $173 \mathrm{~cm} /$ year, and the c. $60 \mathrm{~cm}$ range in MAP corresponds to modeled $304 \Delta_{\text {leaf-MAP }}$ values ranging from 21.1 to $21.7 \%$ and 19.5 to $20.6 \%$ or angiosperms and conifers, respectively. The effect of elevation on $\Delta_{\text {leaf }}$, presumably through reduced atmospheric pressure, has not been included in these calculations, even though modern $\Delta_{\text {leaf }}$ values were observed to decrease as a function of the square root of elevation (e.g., Diefendorf et al., 2010). The Paleogene paleoelevation changes were likely small, $<1 \mathrm{~km}$, although this is poorly constrained (Wing and Greenwood, 1993; McMillan et al., 2006). If all other factors stay equal, then an increase in paleoelevation from 0.5 to $1 \mathrm{~km}$ would translate into a $\Delta_{\text {leaf }}$ decrease of c. $0.5 \%$ (using the equations reported in Diefendorf et al. 2010), a

311 small change that indicates elevation is not an important factor for this study.

313 Combined uncertainty in $\Delta_{\text {leaf-MAP }}$ was estimated using the Monte Carlo method based on the modern314 plant $\Delta_{\text {leaf }}$ correlation with MAP (Diefendorf et al., 2010) and from the upper uncertainties for estimated

315 Paleogene MAP (Table 1); combined uncertainties totaled $\sim 1.9 \%$ and $\sim 3.5 \%$ for angiosperms and 316 conifers, respectively (Table 5). Using a one-at-a-time sensitivity analysis, it was determined that the

317 largest source of error is from the modern $\Delta_{\text {leaf }}$ calibration. This is likely due to the large ranges in $\delta^{13} \mathrm{C}_{\text {leaf }}$ 318 for a given MAP observed in Diefendorf et al. (2010). For example, several sites in the tropics have a 319 range of $\sim 8 \%$ within the same forest, despite averaging values for leaves within a species and restricting analyses to sun exposed canopy leaves (Diefendorf et al., 2010). This variability or 'noise' in $\delta^{13} \mathrm{C}_{\text {leaf }}$ 
321 might be attributed to species effects or to small-scale differences in water availability that are not

322 constrained by climate data in the meta analysis. Regardless, this translates into high uncertainty in the

$323 \Delta_{\text {leaf-MAP }}$ for this study.

Modeled $\Delta_{\text {leaf-MAP }}$ values (based on MAP and taxa) were $0.7 \%$ o $(\mathrm{n}=8$, Wilcoxon Signed Rank, $p=0.016)$ and $0.8 \%$ ( $\mathrm{n}=7$, Wilcoxon Singed Rank, $p=0.048)$ higher than those determined from mean lipid-based $\Delta_{\text {leaf }}$ values calculated from isotope measurements of $n-\mathrm{C}_{29}$ alkanes and triterpenoids, respectively, with a $95 \%$ confidence interval (CI) of $0.5 \%$. For the conifers, lipid-based $\Delta_{\text {leaf }}$ values are not statistically different than the MAP-based modeled conifer $\Delta_{\text {leaf-MAP values }}(\mathrm{n}=8$, Wilcoxon Signed Rank), even when the Latest Paleocene sample is excluded. However, the range in differences is high $(95 \% \mathrm{CI}=0.5$ to $-1.6 \%$; Latest Paleocene excluded) and the $\Delta_{\text {leaf-MAP }}$ uncertainty is also high.

Schubert and Jahren (2012) identified a hyperbolic relationship between $\Delta_{\text {leaf }}$ and $p \mathrm{CO}_{2}$ for two

334 herbaceous angiosperm species grown in well-watered chambers over single generations. For comparison, 335 we calculated $\Delta_{\text {leaf }}$ values as a function of $p \mathrm{CO}_{2}$ (Fig. 5, Table 5) using Equation 6 reported in Schubert 336 and Jahren (2012) and refer to this as $\Delta_{\text {leaf- } p \text { CO2. }}$. Their Equation 6 was based on a compilation of similar 337 studies of that reported $p \mathrm{CO}_{2}$ effects on $\Delta_{\text {leaf }}$, albeit after excluding studies that were not indicative of 338 positive changes in $\Delta_{\text {leaf }}$ with increasing $p \mathrm{CO}_{2} . \Delta_{\text {leaf } p \mathrm{CO} 2}$ values for angiosperms used $p \mathrm{CO}_{2}$ values 339 reported in Beerling and Royer (2011) with means calculated for a 4 million-year time step.

340 Reconstructed $p \mathrm{CO}_{2}$ levels varied between 361 and $946 \mathrm{ppmV}$ (Table 1) with the highest values at the 341 time of deposition of the Eocene Fifteenmile Creek bed. Because of the reconstructed rise in $p \mathrm{CO}_{2}$ 342 between 53 and $51 \mathrm{Ma}$, estimates of $p \mathrm{CO}_{2}$ uncertainty were greater for Fifteenmile Creek than other sites.

343 The closest proxy-based estimate for $p \mathrm{CO}_{2}$ at this time is $814 \pm 240 \mathrm{ppmV}$ at $53.4 \mathrm{Ma}$ (Beerling and 344 Royer, 2011), which is similar to the mean $p \mathrm{CO}_{2}$ value used here. Reported uncertainty in $\Delta_{\text {leaf- } p \mathrm{CO} 2}$ was 345 determined with the Monte Carlo method with the uncertainties in $p \mathrm{CO}_{2}$ estimated for each stratigraphic 
bed. This approach results in larger errors at lower $p \mathrm{CO}_{2}$ because the relationship between $\Delta_{\text {leaf }}$ and $p \mathrm{CO}_{2}$

347 has the greatest slope at low $p \mathrm{CO}_{2}$, thus small changes in $p \mathrm{CO}_{2}$ result in large changes in $\Delta_{\text {leaf. }}$ The

348 uncertainty does not include errors for the parameters of the hyperbolic equation in the report by Shubert

349 and Jahren (2012), who did not report the relationship explicitly. Predicted $\Delta_{\text {leaf } p \mathrm{CO} 2}$ values varied

350 between 21.0 and 24.8, with the highest values at Fifteenmile Creek and Belt Ash (Fig. 5, Table 5).

\section{Discussion}

\subsection{Leaf carbon isotopes based on fossil lipids}

355 Lipid $\delta^{13} \mathrm{C}$ values, when converted to leaf $\delta^{13} \mathrm{C}$ values, allow us to compare $\Delta_{\text {leaf-lipid }}$ for different major 356 plant taxonomic groups. This approach also enables estimates to be employed for comparison with other 357 carbon archives in isotope-based dietary or soil studies. The range in the fractionation associated with

358 lipid biosynthesis, $\varepsilon_{\text {lipid }}$, can be large among species grown under similar climates, and it is currently not 359 well known whether it differs for individual taxa grown under different conditions. Factors such as 360 fixation pathway, growth form, and leaf lifespan are known to be important (Diefendorf et al., 2011; 361 Diefendorf et al., 2012; Magill et al., 2013). However, at present, no systematic study has elucidated 362 environmental or taxonomic controls on $\varepsilon_{\text {lipid }}$, specifically as a function of climate, timing of synthesis, 363 and phylogeny. For this study, we used values from Diefendorf et al. $(2011 ; 2012)$ because: 1) species 364 were chosen specifically in these studies as nearest living relatives to Bighorn Basin species, and 2) 365 species were all grown under similar climatic conditions. Other fractionation factors exist, especially in 366 the tropics (see Magill et al., 2013) and we acknowledge that future studies will revise $n$-alkane $\varepsilon_{\text {lipid }}$ 367 values.

369 Despite current limitations in the state of knowledge regarding $\varepsilon_{\text {lipid }}$, we are encouraged by several 370 patterns that emerge from our dataset. For example, lipid-based leaf $\delta^{13} \mathrm{C}$ values from $n-\mathrm{C}_{29}, n-\mathrm{C}_{31}$ alkanes 
and triterpenoids were similar, which suggests $\varepsilon_{\text {lipid }}$ values from modern calibrations provide consistent

372 leaf $\delta^{13} \mathrm{C}$ values for angiosperms in the Paleogene. Also, calculated conifer $\delta^{13} \mathrm{C}_{\text {leaf }}$ values are c. $2 \%$

373 higher than angiosperms, consistent with comparisons of conifers and angiosperms growing under similar

374 conditions (e.g., Diefendorf et al., 2010).

376 The range in calculated $\delta^{13} \mathrm{C}_{\text {leaf }}$ values across a stratigraphic bed is remarkably small $( \pm 0.5 \%, 1 \sigma)$ given

377 the range of factors that are known to vary and influence leaf $\delta^{13} \mathrm{C}$ values. This low spatial variability in

$378 \delta^{13} \mathrm{C}_{n \text {-alkanes }}$ and thus $\delta^{13} \mathrm{C}_{\text {leaf }}$ is perhaps due to ecological and geologic processes that integrate ecological

379 variability through time and space, such as litter flux, sedimentary transport or the dominance of organic

380 inputs by relatively few, abundant plant species (Graham et al., 2014). In this study, all sites reflect wet

381 floodplain deposition, but TOC and lithology do indeed vary across a stratigraphic bed. The differences in

382 sediment and flora along a bed may reflect patches of slightly better or worse drainage, or other local

383 factors. Perhaps the variation in TOC and lithology reflects variation in redox conditions that are a

384 function of soil depth, soil texture, or flooding frequency across the stratigraphic beds, rather than

385 variability in water that is available to plants, as water was likely abundant. The presence and abundance

386 of plant species and taxonomic groups (e.g. angiosperms and conifers) also typically varies across

387 stratigraphic beds (Davies-Vollum and Wing, 1998), which could give rise to spatial variability in $\delta^{13} \mathrm{C}_{n-}$

388 alkanes because species with different growth forms, phylogeny, and traits (e.g. leaf lifespan) can differ by

389 as much as $8 \%$ with respect to $\Delta_{\text {leaf }}$ even when they grow in the same location (Bonal et al., 2000;

390 Diefendorf et al., 2010). Yet, lipids such as alkanes that are preserved in geologic sediments are almost

391 certainly derived from multiple plant species and multiple generations of plant individuals, and the $\delta^{13} \mathrm{C}$

392 values of preserved lipids are likely weighted toward species that produce more leaves and/or leaf waxes

393 (Graham et al., 2014; Diefendorf et al., 2011). Thus, the $\delta^{13} \mathrm{C}$ value of the preserved lipid pool can be

394 thought of as an "average" $\delta^{13} \mathrm{C}$ value of the lipid inputs, albeit weighted toward plant species that are

395 more abundant through time and space; this also serves to reduce variability of $\delta^{13} \mathrm{C}_{n \text {-alkanes }}$ across a 
stratigraphic bed. Finally, taphonomic processes (i.e. Ellis and Johnson, 2013) may also be important in

397 filtering for certain species and/or leaf sources (canopy versus understory, etc.), but taphonomic effects on

398 the preservation of leaf waxes in geologic sediments have not been well-studied.

\subsection{Modern $\Delta_{\text {leaf }}$ and $\varepsilon_{\text {lipid }}$ calibrations as proxies for paleo- $\Delta_{\text {leaf }}$}

401 We have attempted to compare $\Delta_{\text {leaf }}$ values calculated using lipid biomarkers with those modeled using

402 paleoprecipitation. For lipid-based estimates, $\Delta_{\text {leaf-lipid }}$ values varied no more than $2 \%$ across the eight

403 stratigraphic beds over c. 10 million years of time (Fig. 5). The lipid-based values are in strong agreement

404 with those modeled from MAP despite large changes in temperature $\left(11.7^{\circ} \mathrm{C}\right)$, precipitation $(640 \mathrm{~mm} / \mathrm{yr})$,

405 and atmospheric $\delta^{13} \mathrm{C}(1.5 \%)$ during the early Paleogene. Therefore, we argue that lipid biomarkers can

406 be useful, when constrained by precipitation and taxonomic information, for reconstructing changes in the

407 terrestrial and atmospheric carbon pools in the past.

408

409 Although angiosperm data from different lipids were coherent overall, calculated $\Delta_{\text {leaf-lipid }}$ values are

410 slightly higher, by $0.7 \%$ on average, than modeled $\Delta_{\text {leaf }}$ values that take into account precipitation. It is

411 however important to note that this difference is smaller than calculated uncertainties. Given the

412 similarity in angiosperm $\delta^{13} \mathrm{C}_{\text {leaf }}$ values calculated for $n$-alkanes and triterpenoids, it is unlikely that $\varepsilon_{\text {lipid }}$

413 values are responsible for the offset. The largest offsets between alkane and triterpenoid-based estimates

414 and those based on MAP were for samples representing 63, 57.39, and 56.1 Ma. These times coincide

415 with the lowest and highest $\delta^{13} \mathrm{C}_{\text {atm }}$ values, suggesting that the offset does not reflect changes in $\delta^{13} \mathrm{C}_{\text {atm. }}$

416 The observed offsets could reflect the differential influence of poorly constrained factors, such as paleo-

417 MAT, paleo-MAP, paleo- $p \mathrm{CO}_{2}$ or the modern relationship between $\Delta_{\text {leaf }}$ and MAP. 
Estimates of paleo-MAP for this study were made from leaf area (Wilf et al., 1998), a method with high error. Further, large fossil leaves are not easily preserved and are difficult to recover, which may lead leaf

421 area analyses to underestimate paleo-MAT.

Average annual temperature changed by up to $12^{\circ} \mathrm{C}$ in the Bighorn Basin during the Paleogene. The

424 effects of temperature in modern studies of $\Delta_{\text {leaf }}$ are conflicting (Körner et al., 1991; Diefendorf et al., 2010), potentially because leaves fix most of their carbon within a narrow range of temperature $(21.4 \pm$ $2.2^{\circ} \mathrm{C}$ ) despite a wide range of ambient temperatures (Helliker and Richter, 2008). We find lipidcalculated $\Delta_{\text {leaf }}$ values do not covary with paleotemperature, suggesting temperature does not account for differences between lipid and MAP-based fractionation reconstructions.

Evidence for the effect of $p \mathrm{CO}_{2}$ on $\Delta_{\text {leaf }}$ has been unclear (e.g., Körner et al., 1991; Ehleringer and

431 Cerling, 1995; Polley et al., 1995), potentially because most studies have evaluated short-term $p \mathrm{CO}_{2}$ 432 effects on $\Delta_{\text {leaf }}$ (Beerling and Royer, 2002; Franks and Beerling, 2009) and water availability is often 433 unconstrained (Körner, 2007). Shubert and Jahren (2012) identified a relationship between $\Delta_{\text {leaf }}$ and $p \mathrm{CO}_{2}$ 434 in well-watered chambers for plants grown over single generations. We used this $\Delta_{\text {leaf }} p \mathrm{CO}_{2}$ relationship 435 for our $\mathrm{CO}_{2}$-based modeled leaf fractionation values $\left(\Delta_{\text {leaf }-p \mathrm{CO} 2}\right)$. Although for some samples, $\Delta_{\text {leaf }-p \mathrm{CO} 2}$ 436 agreed nicely with lipid-based $\Delta_{\text {leaf }}$, overall, $\Delta_{\text {leaf- } p \mathrm{CO} 2}$ differed significantly from $\Delta_{\text {leaf-lipid. }}$ For Fifteenmile 437 Creek and Belt Ash stratigraphic beds, high $p \mathrm{CO}_{2}$ estimates led to the highest modeled $\Delta_{\text {leaf- } p \mathrm{CO} 2}$ values. If $438 \quad p \mathrm{CO}_{2}$ were a major control on $\Delta_{\text {leaf }}$ on these timescales, these two wet-depositional sites should have had 439 the highest $\Delta_{\text {leaf-lipid }}$ values, but that was not the case. Although $p \mathrm{CO}_{2}$, and especially geologically brief 440 fluctuations in $p \mathrm{CO}_{2}$, are poorly constrained for this time period, this discrepancy suggests it is premature 441 to use modern $p \mathrm{CO}_{2}-\Delta_{\text {leaf }}$ calibrations to extrapolate to the past, such as for calculating $p \mathrm{CO}_{2}$. 
On short timescales, plants adjust their physiology to optimize leaf gas exchange through stomatal control

444 (Lammertsma et al., 2011). However, on greater than decadal timescales, plants evolve in response to

445 changing $p \mathrm{CO}_{2}$ by adjusting optimal stomatal size and density and by regulating the rate of carbon

446 fixation to maintain optimal set points, including internal to external $\mathrm{CO}_{2}$ concentrations $\left(\mathrm{C}_{\mathrm{i}} / \mathrm{C}_{\mathrm{a}}\right)$

447 (Woodward, 1987; Ehleringer and Cerling, 1995; Woodward and Kelly, 1995; Franks and Beerling, 2009;

448 Franks et al., 2014). Lammertsma et al. (2011) suggested that to study the influence of $p \mathrm{CO}_{2}$ on plants,

449 plant specimens must exhibit structural adaptation. In fact, several studies that have focused on long-term

450 changes ( $>100$ years) on stomatal conductance and $\Delta_{\text {leaf }}$ have observed a small decrease in $\Delta_{\text {leaf }}$ as $p \mathrm{CO}_{2}$

451 increases (Penuelas and Azconbieto, 1992; Bert et al., 1997; Duquesnay et al., 1998; Saurer et al., 2004),

452 exactly opposite of $\Delta_{\text {leaf-pCO2 }}$ patterns predicted by Schubert and Jahren (2011). This may not be surprising

453 given that fossil $\delta^{13} \mathrm{C}$ values over long periods of Earth history are rather consistent (Deines, 1980; Peters-

454 Kottig et al., 2006), which suggests small changes in $C_{i} / C_{a}$ (Franks et al., 2014), despite large changes in

$455 p \mathrm{CO}_{2}$ (Berner and Kothavala, 2001). The stability of terrestrial plant carbon isotope values over geologic

456 time thus may indicate that optimum $\Delta_{\text {leaf }}$ values are maintained on long geologic timescales, as suggested

457 by Ehleringer and Cerling (1995). Thus, results from growth chambers must be used cautiously with

458 respect to geologic interpretations, particularly for plant characteristics that likely evolve on timescales

459 longer than one generation (e.g. $\Delta_{\text {leaf }}$ responsiveness to $p \mathrm{CO}_{2}$ ).

460

\subsection{Uncertainties and implications for the geologic record}

462 Modern studies of carbon isotope fractionation during photosynthesis and biomarker synthesis can

463 provide a foundation to account for the competing influences of climate, lipid biosynthesis, and

464 taxonomic group when interpreting changes in $\Delta_{\text {leaf }}$ based on lipid $\delta^{13} \mathrm{C}$ values in the past. However, the

465 uncertainties on $\Delta_{\text {leaf-lipid }}$ in the past are high $( \pm 2 \%)$ because of the variability in modern $\Delta_{\text {leaf }}$ and $\varepsilon_{\text {lipid }}$

466 values. If these sources of uncertainty are applicable to the geologic record and are representative of a

467 forest, then the $\Delta_{\text {leaf }}$ range observed in modern forests (e.g., Bonal et al., 2000; Diefendorf et al., 2010) 
should be considered as a very conservative starting point for estimating the possible uncertainty in geologic $\delta^{13} \mathrm{C}$ records. This would require that all studies take modern $\Delta_{\text {leaf }}$ variability into account when interpreting variation in $\delta^{13} \mathrm{C}$ values of organic matter in geologic and modern sediments, at least as a first

471 order approximation of the uncertainty. As mentioned above, variability in the stratigraphic beds studied

472 here is much smaller than the range observed in a single forest (Bonal et al., 2000), either because the

473 variability is small for $\delta^{13} \mathrm{C}$ values of organic matter that is delivered to sediments (generally $50 \%$ or more

474 carbon in forest litter is from leaves; Graham et al., 2014) or processes reduce the variability, such as time 475 averaging, spatial averaging, or taphonomic effects. Combined, factors that reduce variability may also 476 reduce uncertainty, but future studies will need to determine if that is the case. Nonetheless, on larger 477 spatial scales or over time, variations in $\delta^{13} \mathrm{C}$ values will be caused by changes in climate and taxonomic 478 group through their pervasive influences on $\Delta_{\text {leaf }}$ and $\varepsilon_{\text {lipid. }}$ Corrections for these controlling factors must 479 be made to interpret $\delta^{13} \mathrm{C}$ values in terrestrial sediments for bulk or lipid-based approaches. For example, 480 if $\delta^{13} \mathrm{C}$ values of $n$-alkanes are to be used to interpret changes in water use efficiency through time, then 481 the effect of changing taxonomic group (controls on $\Delta_{\text {leaf }}$ and $\varepsilon_{\text {lipid }}$ ) and $\delta^{13} \mathrm{C}_{\text {atm }}$ must be removed, or at 482 least ruled out as a control, to realistically interpret $\delta^{13} \mathrm{C}$ values of $n$-alkanes.

Using the approach described above, we find that over a 10 million year period marked by substantial climatic changes, calculated $\Delta_{\text {leaf-lipid }}$ values were similar to modeled $\Delta_{\text {leaf-MAP }}$ values (based on paleoprecipitation and the relationship between $\Delta_{\text {leaf }}$ of living plants and precipitation). The measured 487 uncertainties placed on both calculated $\Delta_{\text {leaf-lipid }}$ and modeled $\Delta_{\text {leaf-MAP }}$ are similar in magnitude and, 488 importantly, the predicted range of values overlap (Fig. 5). Nonetheless, the measured uncertainties are 489 large and can most likely be attributed to the biological variability in modern $\varepsilon_{\text {lipid }}$ and $\Delta_{\text {leaf-MAP. To reduce }}$ 490 this biological variability, more systematic studies of the influences of climate, species/phylogeny, growth 491 form, and timing of synthesis on $\varepsilon_{\text {lipid }}$ and $\Delta_{\text {leaf }}$ are required to determine the best $\varepsilon_{\text {lipid }}$ and $\Delta_{\text {leaf }}$ values to 492 use for geologic studies. One of the challenges is designing studies with one independent variable to 
evaluate the effect on fractionation. For example, studying the influence of precipitation on $\varepsilon_{\text {lipid }}$ and $\Delta_{\text {leaf }}$

494 requires a precipitation gradient where all other factors, including species, are held constant or otherwise

495 reasonably accounted for (e.g. using multivariate statistical approaches). The former approach is difficult

496 because there is tremendous species turnover across precipitation gradients.

497

498 When interpreting changes in $\delta^{13} \mathrm{C}$ records, the influence of climate on $\varepsilon_{\text {lipid }}$ and $\Delta_{\text {leaf }}$ is likely most 499 important during carbon isotope excursions (CIEs), such as occurred during the Paleocene-Eocene 500 Thermal Maximum (PETM). Based on a recent review by McInerney and Wing (2011), the range in 501 terrestrial CIEs during the PETM is large, from -2.2 to -7.6\%. Reconciling the magnitude of these 502 terrestrial CIEs has been challenging for many reasons (see McInerney and Wing, 2011). The degree to 503 which the range in CIEs recorded by plant biomarkers is caused by changes in $\varepsilon_{\text {lipid }}$ and $\Delta_{\text {leaf }}$ is unclear, but 504 to our knowledge, no studies have estimated the uncertainties in CIEs due to changes in $\Delta_{\text {leaf }}$ or $\varepsilon_{\text {lipid. }}$ 505 Other factors, such as $p \mathrm{CO}_{2}$, may be important controls on fractionation in general (Schubert and Jahren, 506 2012) and for the PETM (Schubert and Jahren, 2013), but it is unclear if the rate of change at the onset of 507 the PETM is too fast for plants to evolve and acclimate to higher $p \mathrm{CO}_{2}$.

\section{Conclusions}

511 Plant lipid $\delta^{13} \mathrm{C}$ values were measured from eight stratigraphic beds in the Bighorn Basin from 63 to 53

512 Ma. We found that calculated $\delta^{13} \mathrm{C}_{\text {leaf }}$ values were similar for angiosperm-specific lipids ( $n$-alkanes,

513 triterpenoids), indicating that Paleogene $\varepsilon_{\text {lipid }}$ values for $n$-alkanes and triterpenoids were similar to

514 modern values. Also, $\delta^{13} \mathrm{C}_{\text {leaf }}$ values calculated from conifer diterpenoids were $2 \%$ higher than

515 angiosperm values and this is similar to the expected offset for modern angiosperms and conifers grown 516 under the same climate (e.g., Diefendorf et al., 2010). 
518 We found that calculated and modeled $\Delta_{\text {leaf-MAP }}$ values were similar, although offset by $\sim 0.7 \%$. The

519 ability to model paleo- $\Delta_{\text {leaf }}$ values using modern relationships with precipitation suggests that $\Delta_{\text {leaf-lipid }}$ of

520 Paleogene plants was shaped by water availability, major taxonomic group, and biosynthetic fractionation

521 in a manner similar to living plants. If the modern data were not applicable to the past for some reason,

522 then our modeled $\Delta_{\text {leaf-MAP }}$ values would likely not correspond to calculated $\Delta_{\text {leaf-lipid }}$ values as well as they

523 do. The small observed offset could be caused by several factors, but importantly the offset is relatively

524 consistent, suggesting a common factor. In order to better interpret $\delta^{13} \mathrm{C}$ values in the geological past,

525 future studies must determine what causes the large variability in modern $\Delta_{\text {leaf }}$ and $\varepsilon_{\text {lipid. }}$.

527 Two stratigraphic beds represent times when $p \mathrm{CO}_{2}$ levels are thought to have been higher than today.

528 These beds did not have elevated calculated $\Delta_{\text {leaf-lipid }}$ values as would be expected based on modern growth

529 chamber studies, supporting the idea that $\Delta_{\text {leaf }}$ is insensitive to $p \mathrm{CO}_{2}$ when plants have sufficient time to

530 acclimate to $p \mathrm{CO}_{2}$. If changes in stomatal size and density are any indicator, then changes in $p \mathrm{CO}_{2}$ must

531 be longer than a decade for the long-term effect on $\Delta_{\text {leaf }}$ to be observed (e.g., Lammertsma et al., 2011).

532 Therefore growth chamber studies may be of limited utility and future studies of $\mathrm{CO}_{2}$ effects on $\Delta_{\text {leaf }}$

533 should focus on plants that have adapted to $p \mathrm{CO}_{2}$ changes over longer timescales. We show here that,

534 with careful consideration of factors such as paleoprecipitation and reconstructed atmospheric $\delta^{13} \mathrm{C}$

535 values, the $\delta^{13} \mathrm{C}$ values of plant biomarkers in geologic sediments might offer a promising tool of

536 evaluating the effects of past changes in $p \mathrm{CO}_{2}$ on leaf physiology.

\section{Acknowledgements}

We thank Francesca McInerney and Dana Royer for their thoughtful reviews. This research was

541 supported by the National Science Foundation (NSF) Grants EAR-0844212 (K.H.F.) and EAR-1229114

542 (A.F.D.), fellowship awards from the Penn State Biogeochemical Research Initiative for Education

543 (BRIE) funded by NSF IGERT Grant DGE-9972759, an American Chemical Society PRF Grant \#51787- 
544 DNI2 (A.F.D.), and the Roland W. Brown Fund of the Smithsonian Institution (E.D.C).

545

546

547

548

549 


\section{References}

551 Anderson, G.M., 1976. Error propagation by the Monte Carlo method in geochemical calculations.

552 Geochim. Cosmochim. Acta 40, 1533-1538.

553 Beerling, D.J., Royer, D.L., 2002. Fossil plants as indicators of the Phanerozoic global carbon cycle.

554 Annu Rev Earth Planet Sci 30, 527-556.

555 Beerling, D.J., Royer, D.L., 2011. Convergent Cenozoic $\mathrm{CO}_{2}$ history. Nature Geosci 4, 418-420.

556 Berner, R.A., Kothavala, Z., 2001. Geocarb III: A Revised Model of Atmospheric $\mathrm{CO}_{2}$ over Phanerozoic

557 Time. Am J Sci 301, 182-204.

558 Bert, D., Leavitt, S.W., Dupouey, J.-L., 1997. Variations of wood $\delta^{13} \mathrm{C}$ and water-use efficiency of Abies

559 alba during the last century. Ecology 78, 1588-1596.

560 Bonal, D., Sabatier, D., Montpied, P., Tremeaux, D., Guehl, J.M., 2000. Interspecific variability of $\delta^{13} \mathrm{C}$

561 among trees in rainforests of French Guiana: functional groups and canopy integration. Oecologia 124,

$562 \quad 454-468$.

563 Bowen, G.J., 2013. Up in smoke: A role for organic carbon feedbacks in Paleogene hyperthermals.

564 Global and Planetary Change 109, 18-29.

565 Bown, T.M., 1980. The Willwood Formation (lower Eocene) of the southern Bighorn Basin, Wyoming, 566 and its mammalian fauna, in: Gingerich, P.D. (Ed.), Early Cenozoic Paleontology and Stratigraphy of the 567 Bighorn Basin, Wyoming, 1880-1980. University of Michigan Papers on Paleontology 24, pp. 127-138.

568 Bush, R.T., McInerney, F.A., 2013. Leaf wax $n$-alkane distributions in and across modern plants:

569 Implications for paleoecology and chemotaxonomy. Geochim. Cosmochim. Acta 117, 161-179.

570 Cernusak, L.A., Ubierna, N., Winter, K., Holtum, J.A.M., Marshall, J.D., Farquhar, G.D., 2013.

571 Environmental and physiological determinants of carbon isotope discrimination in terrestrial plants. New

572 Phytol. 200, 950-965.

573 Currano, E.D., Labandeira, C.C., Wilf, P., 2010. Fossil insect folivory tracks paleotemperature for six 574 million years. Ecological Monographs 80, 547-549. 

increased insect herbivory during the Paleocene-Eocene Thermal Maximum. Proc. Natl. Acad. Sci. U.S.A. $105,1960-1964$.

Davies-Vollum, K.S., Wing, S.L., 1998. Sedimentological, taphonomic, and climatic aspects of Eocene swamp deposits (Willwood Formation, Bighorn Basin, Wyoming). PALAIOS 13, 28-40. Deines, P., 1980. The isotopic composition of reduced organic carbon, in: Fritz, P., Fontes, J.C. (Eds.),

581 Handbook of Environmental Isotope geochemistry. Elsevier, Amsterdam, pp. 329-406.

582 Diefendorf, A.F., Freeman, K.H., Wing, S.L., 2012. Distribution and carbon isotope patterns of

583 diterpenoids and triterpenoids in modern temperate $\mathrm{C}_{3}$ trees and their geochemical significance. Geochim.

584 Cosmochim. Acta 85, 342-356.

585 Diefendorf, A.F., Freeman, K.H., Wing, S.L., 2014. A comparison of terpenoid and leaf fossil vegetation 586 proxies in Paleocene and Eocene Bighorn Basin sediments. Org. Geochem. 71, 30-42.

587 Diefendorf, A.F., Freeman, K.H., Wing, S.L., Graham, H.V., 2011. Production of $n$-alkyl lipids in living 588 plants and implications for the geologic past. Geochim. Cosmochim. Acta 75, 7472-7485.

589 Diefendorf, A.F., Mueller, K.E., Wing, S.L., Koch, P.L., Freeman, K.H., 2010. Global patterns in leaf $59013 \mathrm{C}$ discrimination and implications for studies of past and future climate. Proc. Natl. Acad. Sci. U.S.A. $591 \quad 107,5738-5743$.

592 Duquesnay, A., Bréda, N., Stievenard, M., Dupouey, J.L., 1998. Changes of tree-ring $\delta^{13}$ C and water-use 593 efficiency of beech (Fagus sylvatica L.) in north-eastern France during the past century. Plant, Cell \& 594 Environment 21, 565-572.

595 Ehleringer, J.R., Cerling, T.E., 1995. Atmospheric $\mathrm{CO}_{2}$ and the ratio of intercellular to ambient $\mathrm{CO}_{2}$ 596 concentrations in plants. Tree Phys 15, 105-111.

597 Farquhar, G.D., Ehleringer, J.R., Hubick, K.T., 1989. Carbon isotope discrimination and photosynthesis. 598 Annu. Rev. Plant Phys. Plant Biol. 40, 503-537.

599 Franks, P.J., Beerling, D.J., 2009. $\mathrm{CO}_{2}$ forced evolution of plant gas exchange capacity and water-use 600 efficiency over the Phanerozoic. Geobiology 7, 227-236. 
601

602

603

604

605

606

607

608

609

610

611

612

613

614

615

616

617

618

619

620

621

622

623

624

625

626

Franks, P.J., Royer, D.L., Beerling, D.J., Van de Water, P.K., Cantrill, D.J., Barbour, M.M., Berry, J.A., 2014. New constraints on atmospheric CO2 concentration for the Phanerozoic. Geophysical Research Letters 41, 2014GL060457.

Freeman, K.H., Mueller, K.E., Diefendorf, A.F., Wing, S.L., Koch, P.L., 2011. Clarifying the influence of water availability and plant types on carbon isotope discrimination by C3 plants. Proc. Natl. Acad. Sci. U.S.A. 108, E59-E60.

Graham, H.V., Patzkowsky, M.E., Wing, S.L., Parker, G.G., Fogel, M.L., Freeman, K.H., 2014. Isotopic characteristics of canopies in simulated leaf assemblages. Geochim. Cosmochim. Acta 144, 82-95.

Hayes, J.M., 2001. Fractionation of carbon and hydrogen isotopes in biosynthetic processes. Rev. Mineral Geochem. 43, 225-277.

Helliker, B.R., Richter, S.L., 2008. Subtropical to boreal convergence of tree-leaf temperatures. Nature $454,511-514$.

Jones, H.L., Hajek, E.A., 2007. Characterizing avulsion stratigraphy in ancient alluvial deposits.

Sedimentary Geology 202, 124-137.

Kolattukudy, P., Croteau, R., Buckner, J., 1976. Biochemistry of plant waxes, in: Kolattukudy, P. (Ed.), Chemistry and Biochemistry of Natural Waxes. Elsevier, Amsterdam, pp. 289-347.

Körner, C., 2007. The use of 'altitude' in ecological research. Trends in Ecology \& Evolution 22, 569-574.

Körner, C.H., Farquhar, G.D., Wong, S.C., 1991. Carbon isotope discrimination by plants follows

latitudinal and altitudinal trends. Oecologia 88, 30-40.

Lammertsma, E.I., Boer, H.J.d., Dekker, S.C., Dilcher, D.L., Lotter, A.F., Wagner-Cremer, F., 2011.

Global $\mathrm{CO}_{2}$ rise leads to reduced maximum stomatal conductance in Florida vegetation. Proc. Natl. Acad. Sci. U.S.A. 108, 4035-4040.

Magill, C.R., Ashley, G.M., Freeman, K.H., 2013. Ecosystem variability and early human habitats in eastern Africa. Proc. Natl. Acad. Sci. U.S.A. 110, 1167-1174.

McInerney, F.A., Wing, S.L., 2011. The Paleocene-Eocene Thermal Maximum: A perturbation of carbon cycle, climate, and biosphere with implications for the future. Annu. Rev. Earth Planet. Sci. 39, 489-516. 
McMillan, M.E., Heller, P.L., Wing, S.L., 2006. History and causes of post-Laramide relief in the Rocky Mountain orogenic plateau. Geo Soc Am Bull 118, 393-405.

629 Penuelas, J., Azconbieto, J., 1992. Changes in leaf delta-C-13 of herbarium plant-species during the last 3 630 centuries of $\mathrm{CO}_{2}$ Increase. Plant Cell Environ 15, 485-489.

631 Peters-Kottig, W., Strauss, H., Kerp, H., 2006. The land plant $\delta^{13}$ C record and plant evolution in the Late 632 Palaeozoic. Palaeogeogr. Palaeocl. Palaeoecol. 240, 237-252.

633 Polley, H.W., Johnson, H.B., H.S., M., 1995. Nitrogen and water requirements of C3 plants grown at 634 glacial to present carbon dioxide concentrations. Func. Ecol. 9, 86-96.

635 Saurer, M., Siegwolf, R.T.W., Schweingruber, F.H., 2004. Carbon isotope discrimination indicates 636 improving water-use efficiency of trees in northern Eurasia over the last 100 years. Global Change Bio $63710,2109-2120$.

638 Schubert, B.A., Jahren, A.H., 2012. The effect of atmospheric $\mathrm{CO}_{2}$ concentration on carbon isotope 639 fractionation in C3 land plants. Geochim. Cosmochim. Acta 96, 29-43.

640 Schubert, B.A., Jahren, A.H., 2013. Reconciliation of marine and terrestrial carbon isotope excursions 641 based on changing atmospheric $\mathrm{CO}_{2}$ levels. Nat Commun 4, 1653.

642 Tipple, B.J., Meyers, S.R., Pagani, M., 2010. Carbon isotope ratio of Cenozoic $\mathrm{CO}_{2}$ : A comparative 643 evaluation of available geochemical proxies. Paleoceanography 25, PA3202.

644 Wilf, P., Wing, S.L., Greenwood, D.R., Greenwood, C.L., 1998. Using fossil leaves as paleoprecipitation 645 indicators: An Eocene example. Geology 26, 203-206.

646 Wing, S.L., 1984. Relation of paleovegetation to geometry and cyclicity of some fluvial carbonaceous 647 deposits. Journal of Sedimentary Petrology 54, 52-66.

648 Wing, S.L., Bao, H., Koch, P.L., 2000. An early Eocene cool period? Evidence for continental cooling 649 during the warmest part of the Cenozoic, in: Huber, B.T., MacLeod, K.G., Wing, S.L. (Eds.), Warm 650 Climates in Earth History. Cambridge University Press, New York, pp. 197-236.

651 Wing, S.L., Currano, E.D., 2013. Plant response to a global greenhouse event 56 million years ago. Amer 652 J Bot 100, 1234-1254. 
653 Wing, S.L., Greenwood, D.R., 1993. Fossils and fossil climate: the case for equable continental interiors 654 in the Eocene. Philosophical Transactions of the Royal Society of London. Series B-Biological Sciences $655341,243-252$.

656 Wing, S.L., Harrington, G.J., Smith, F.A., Bloch, J.I., Boyer, D.M., Freeman, K.H., 2005. Transient floral 657 change and rapid global warming at the Paleocene-Eocene boundary. Science 310, 993-996.

658 Woodward, F.I., 1987. Stomatal numbers are senstitive to increased CO2 from pre-industrial levels.

$659 \quad$ Nature 327, 617-618.

660 Woodward, F.I., Kelly, C.K., 1995. The influence of $\mathrm{CO}_{2}$ concentration on stomatal density. New Phytol. $661 \quad 131,311-327$.

662

663

664 


\section{Figure Captions}

Figure 1. A) Lipids and their carbon isotope $\left(\delta^{13} \mathrm{C}_{\text {lipid }}\right)$ values are preserved in the geologic record and provide a link to leaf $\delta^{13} \mathrm{C}\left(\delta^{13} \mathrm{C}_{\text {leaf }}\right)$, after constraining for fractionation that occurs during lipid biosynthesis $\left(\varepsilon_{\text {lipid }}\right)$, or to atmospheric $\mathrm{CO}_{2} \delta^{13} \mathrm{C}$ values $\left(\delta^{13} \mathrm{C}_{\text {atm }}\right)$, after constraining for fractionation that occurs during photosynthesis $\left(\Delta_{\text {leaf }}\right)$. Alternatively, $\Delta_{\text {leaf }}$ can be calculated if $\delta^{13} \mathrm{C}_{\text {atm }}$ is known, and this provides a measure of discrimination which can be useful for interpreting water availability, ecophysiology, vegetation information, etc. (see text for details). B) In this study, $\Delta_{\text {leaf }}$ is calculated (Calculated $\Delta_{\text {leaf-lipid }}$ from sedimentary lipid $\delta^{13} \mathrm{C}$ values, after controlling for fractionation during lipid biosynthesis and using $\delta^{13} \mathrm{C}_{\text {atm }}$ values derived from benthic foraminifera. Calculated $\Delta_{\text {leaf-lipid }}$ values are then compared to modeled $\Delta_{\text {leaf }}$ values based on modern plant studies. $\Delta_{\text {leaf }}$ values are modeled for both angiosperms and conifers using modern relationships between $\Delta_{\text {leaf }}$ and plant type and paleoprecipitation (Modeled $\Delta_{\text {leaf-MAP }}$ ). Also, $\Delta_{\text {leaf }}$ values are modeled for angiosperms using modern $\Delta_{\text {leaf }}$ relationships between $\Delta_{\text {leaf }}$ and $p \mathrm{CO}_{2}$. The various sources of inputs are as follows: ${ }^{\mathrm{A}}$ This study; ${ }^{\mathrm{B}}$ Diefendorf et al. (2011, 2012); ${ }^{\mathrm{C}}$ Tipple et al. (2010); ${ }^{\mathrm{D}}$ Currano et al. (2008, 2012), ${ }^{\mathrm{E}}$ Diefendorf et al. (2010); ${ }^{\mathrm{F}}$ Beerling and Royer (2011), ${ }^{\mathrm{G}}$ Schubert and Jahren (2012).

Figure 2. Location of the Bighorn Basin within the USA and location of sampling sites within the Bighorn Basin.

Figure 3. Selected geochemical data including total $n$-alkane concentrations, average chain length (ACL), diterpenoid concentrations for all compounds and for abietatriene (structure shown), and triterpenoid concentrations for all compounds and for 2,2,4a,9-Tetramethyl-1,2,3,4,4a,5,6,14b-octahydropicene (structure shown) for all stratigraphic beds. See Diefendorf et al. (2014) for additional geochemical data. 
690 Figure 4. Total organic carbon (TOC), lipid and atmospheric $\delta^{13} \mathrm{C}$ data for all stratigraphic beds. $\delta^{13} \mathrm{C}_{\text {atm }}$ 691 values are from Tipple et al. (2010) and are shown with the reported 90\% confidence interval.

693 Figure 5. Carbon isotope fractionation $\left(\Delta_{\text {leaf }}\right)$ separated by conifer and angiosperm taxonomic groups and 694 C) $p \mathrm{CO}_{2}$ estimates from Beerling and Royer (2011) and present-day $p \mathrm{CO}_{2}$ indicated with a dashed line. 695 Symbols (circles or triangles) denote mean calculated $\Delta_{\text {leaf-lipid }}$ values for a stratigraphic bed as measured 696 for $n-\mathrm{C}_{29}$ alkanes, triterpenoids or diterpenoids. Vertical lines are total uncertainties $(1 \sigma)$ in the calculated $697 \Delta_{\text {leaf-lipid. }}$ Shaded boxes are the modeled $\Delta_{\text {leaf }}$ values from the modern $\Delta_{\text {leaf }}$ calibrations based on mean 698 annual precipitation (MAP) with the central horizontal line indicating the mean and the shaded area 699 indicating the total uncertainty $(1 \sigma)$. Dashed boxes indicate the modeled $\Delta_{\text {leaf }}$ values as a function of 700 atmospheric $p \mathrm{CO}_{2}$ from Schubert and Jahren (2012) with the central horizontal line indicating the mean 701 and uncertainty shown by the outer box. All samples and boxes were widened relative to their absolute 702 age (Table 1) for visual representation on this figure (i.e. alkane and angiosperm values were separated in 703 time to remove overlap). The Latest Paleocene (56.04 Ma) and the Honeycombs (56.1 Ma) beds were 704 additionally graphically separated to improve visual presentation and are denoted by the grey box at 56 705 Ma. 
Figure 1

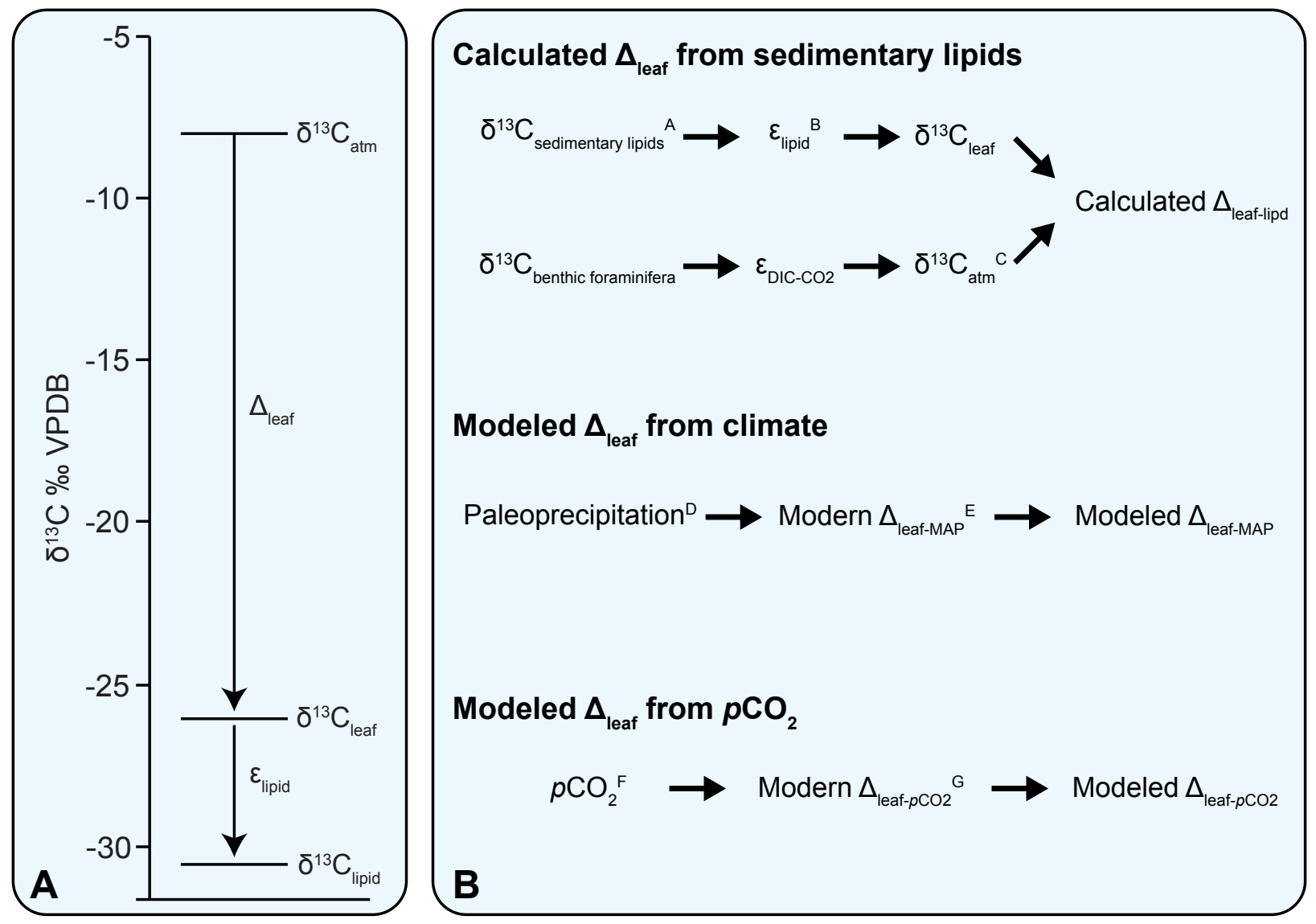




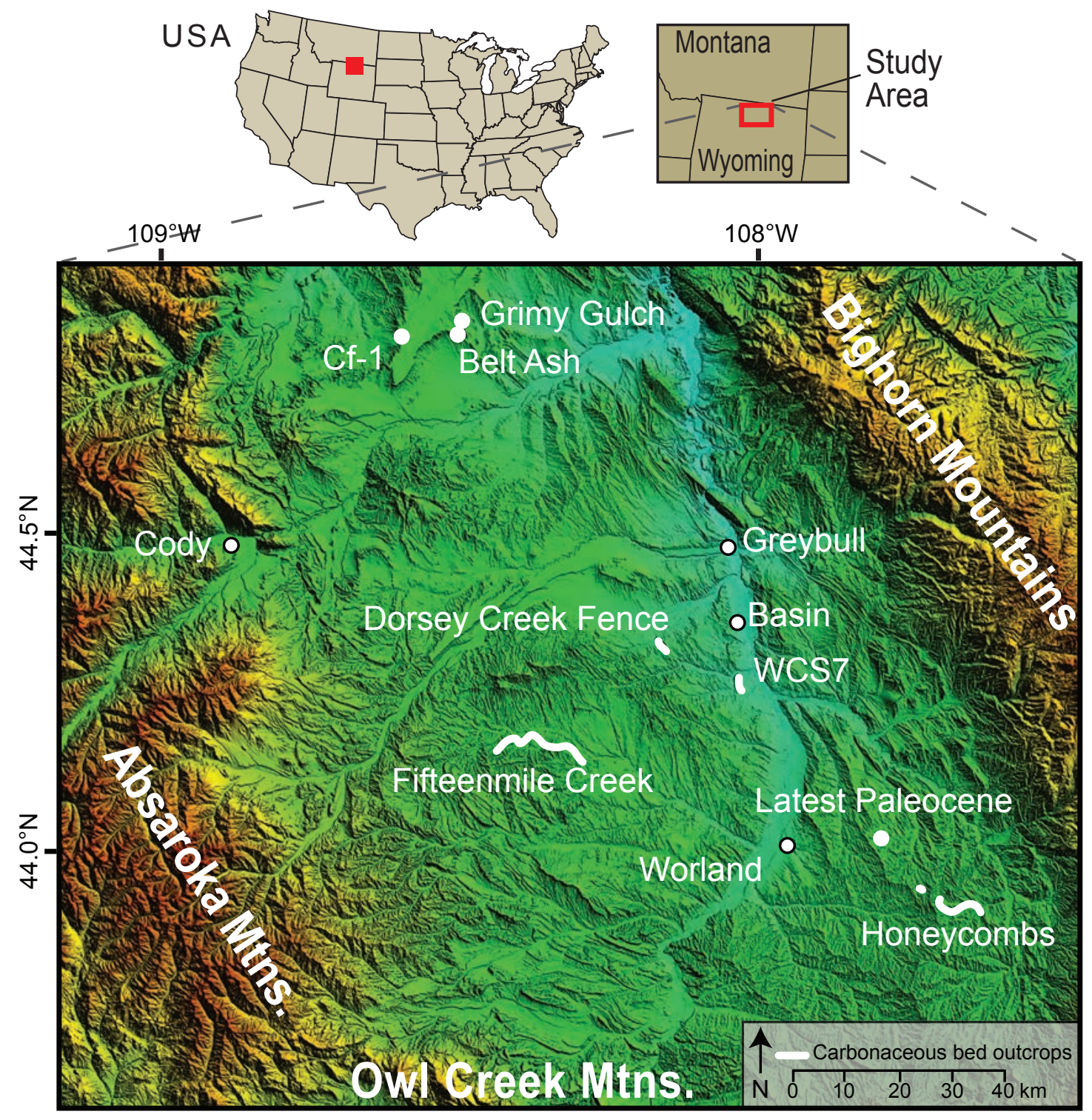


Figure 3

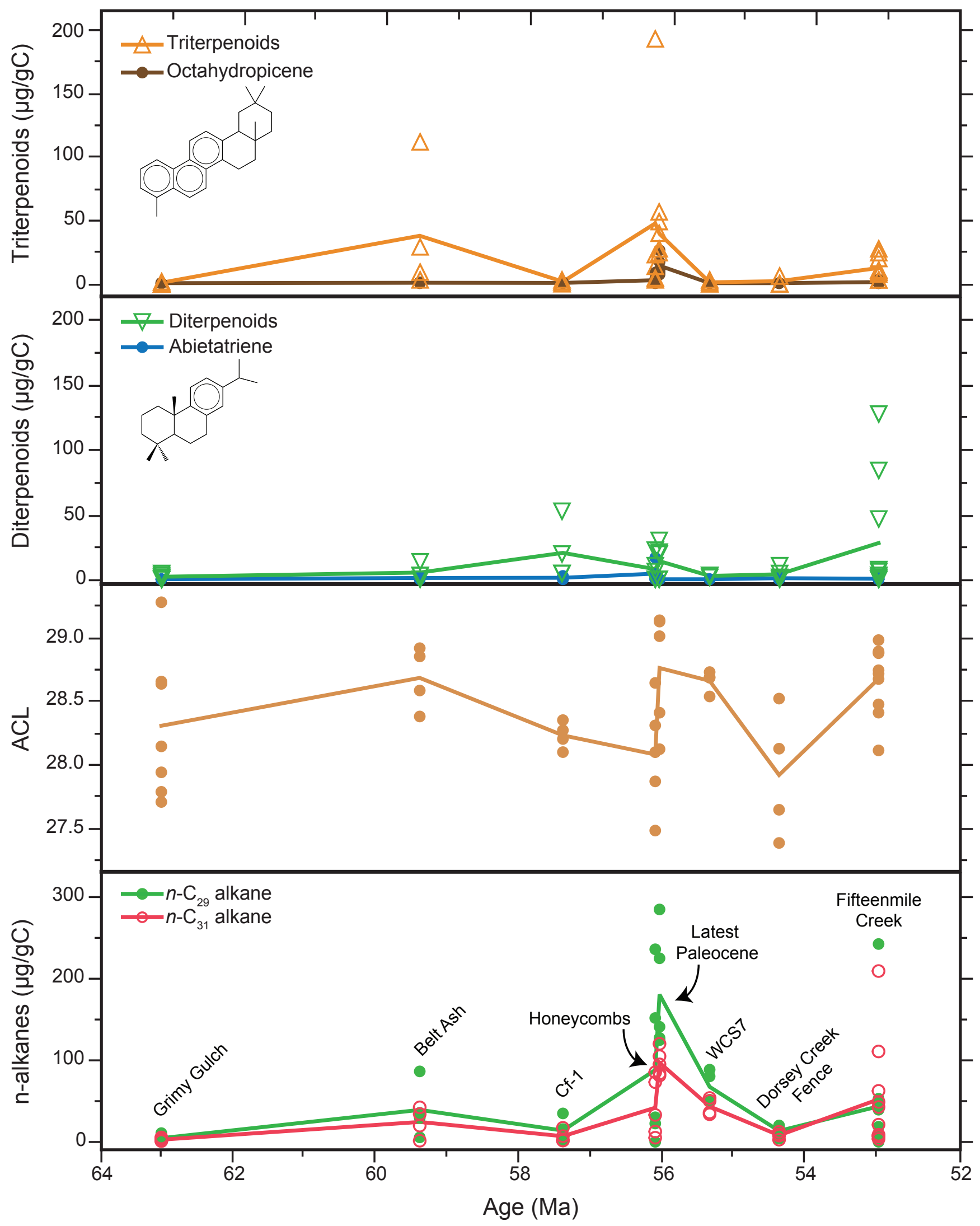




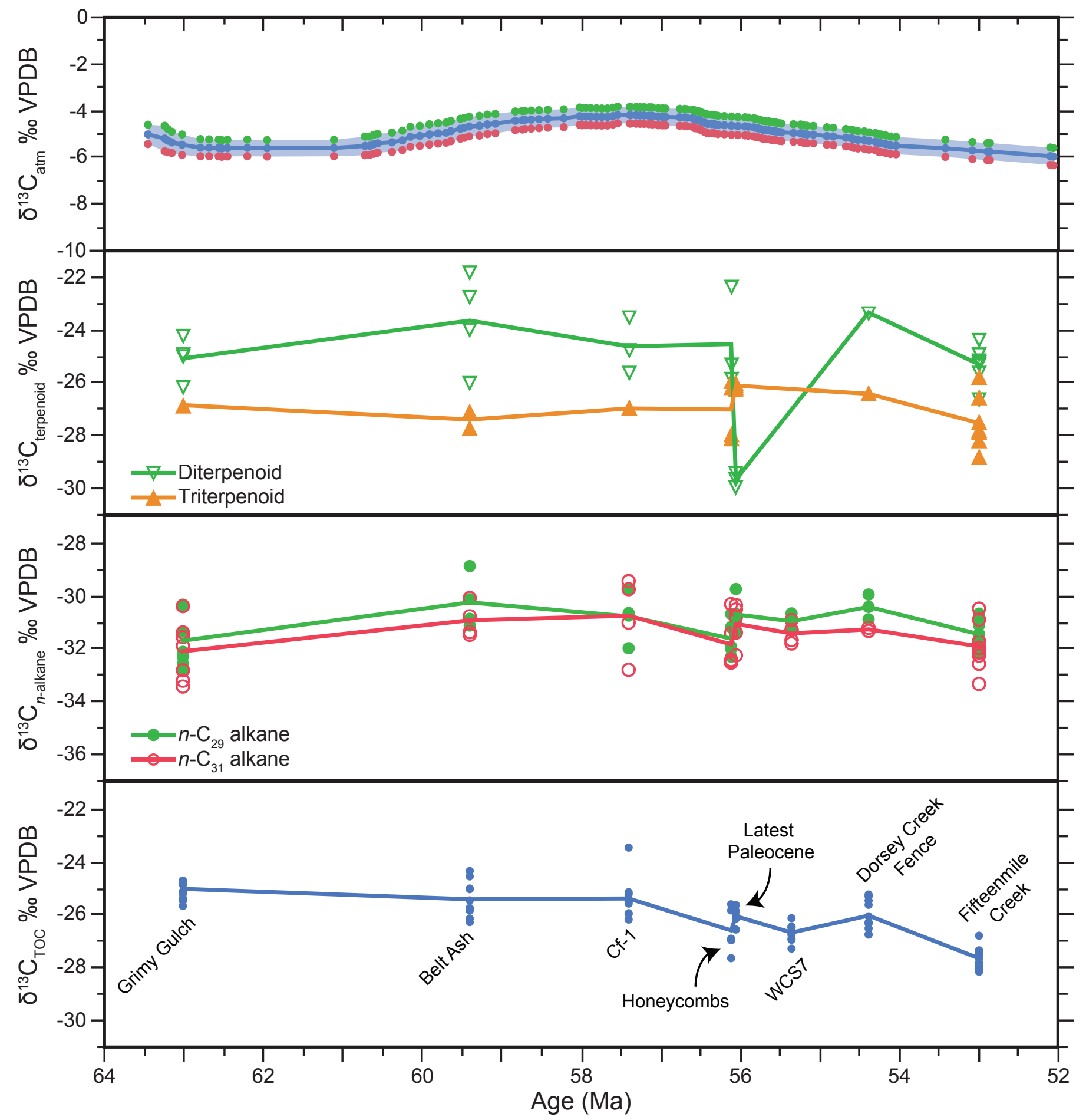




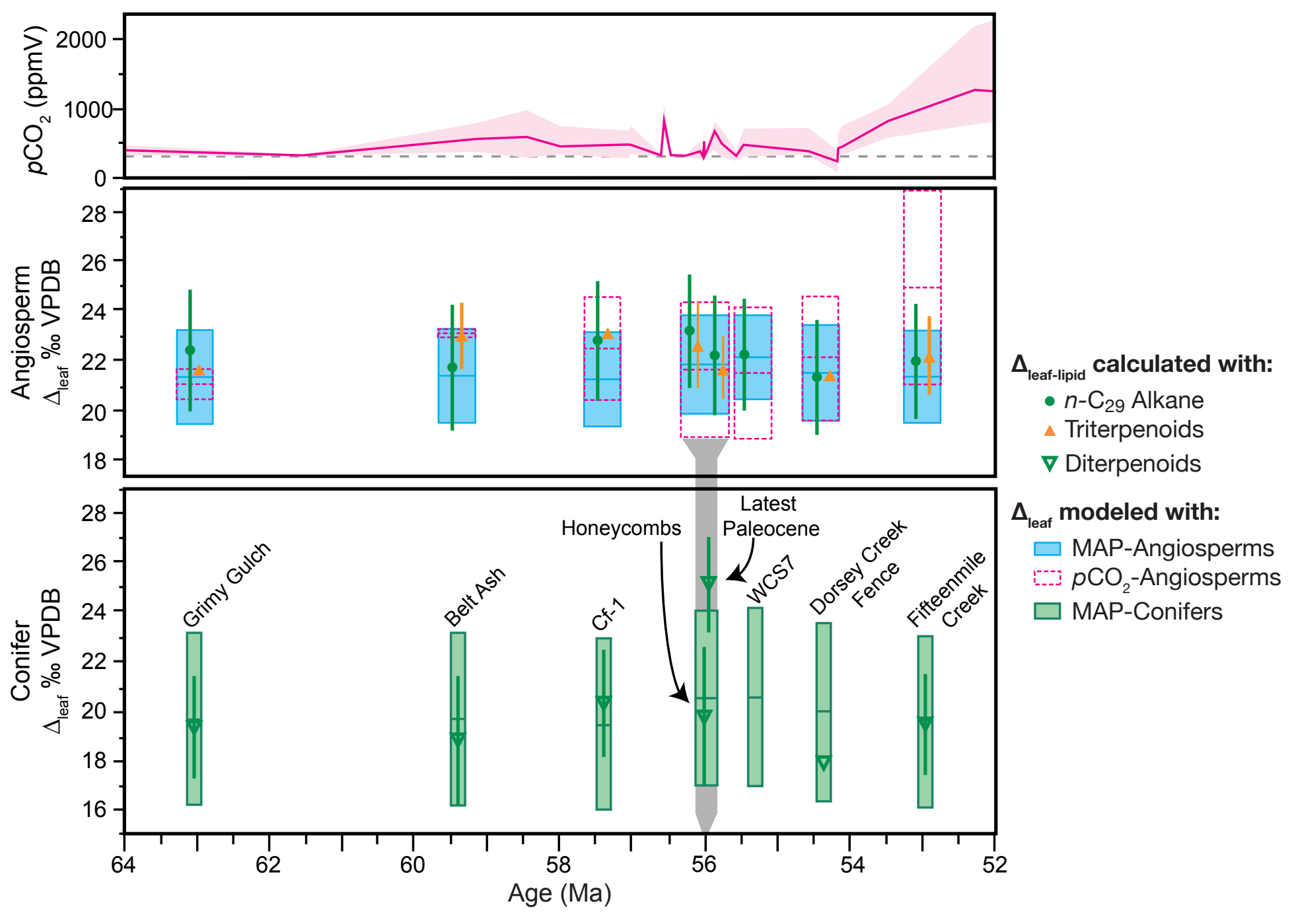




\section{Tables}

Table 1. Bed names, stratigraphic and age information, paleovegetation and paleoclimate.

\begin{tabular}{|c|c|c|c|c|c|c|c|c|c|}
\hline Bed Name & Level m (Section) ${ }^{a}$ & Epoch & Formation & Age (Ma) & $\begin{array}{c}\text { Conifer } \\
\text { Paleovegetation } \\
\%^{\mathrm{b}}\end{array}$ & $\begin{array}{c}\text { MAP } \\
\mathbf{c m}, \pm 1 \mathrm{SE}^{\mathrm{c}}\end{array}$ & $\begin{array}{l}\text { MAT } \\
{ }^{\circ} \mathbf{C}^{\mathbf{d}}\end{array}$ & $\begin{array}{c}p \mathrm{CO}_{2} \\
\operatorname{ppmV}, \pm 1 \sigma^{\mathrm{f}}\end{array}$ & $\begin{array}{c}\delta^{13} \mathrm{C}_{\text {atm }} \\
\% \text {, } \pm 90 \% \mathrm{CI}^{\mathrm{g}}\end{array}$ \\
\hline Fifteenmile Creek & $700 \mathrm{~m}(\mathrm{ECS})$ & Eocene & Willwood & 52.98 & 3 to 9 & $114(+49,-34)$ & $22.2 \pm 2.0$ & $946 \pm 633$ & $-5.8 \pm 0.4$ \\
\hline Dorsey Creek Fence & $353 \mathrm{~m}(\mathrm{ECS})$ & Eocene & Willwood & 54.37 & $\leq 5$ & $132(+57,-40)$ & $10.8 \pm 3.3$ & $456 \pm 171$ & $-5.3 \pm 0.4$ \\
\hline WCS7 & $112 \mathrm{~m}(\mathrm{ECS})$ & Eocene & Willwood & 55.34 & $\leq 5$ & $173^{\mathrm{e}}$ & $16.4 \pm 2.7$ & $394 \pm 153$ & $-5.0 \pm 0.4$ \\
\hline Latest Paleocene & $7.5 \mathrm{~m}$ below CIE & Paleocene & Fort Union & 56.04 & $\leq 5$ & $173(+75,-52)$ & $16.4 \pm 2.9$ & $405 \pm 162$ & $-4.7 \pm 0.4$ \\
\hline Honeycombs & 13 m below CIE & Paleocene & Fort Union & 56.1 & $\leq 14$ & $173^{\mathrm{e}}$ & $16.4 \pm 2.9$ & $405 \pm 162$ & $-4.7 \pm 0.4$ \\
\hline $\mathrm{Cf}-1$ & $429 \mathrm{~m}$ (WPB) & Paleocene & Fort Union & 57.39 & $\leq 5$ & $109(+47,-33)$ & $12.0 \pm 2.9$ & $451 \pm 167$ & $-4.2 \pm 0.4$ \\
\hline Belt Ash & $351 \mathrm{~m}$ (SPB) & Paleocene & Fort Union & 59.39 & $\leq 5$ & $120(+52,-36)$ & $10.5 \pm 2.9$ & $564 \pm 26$ & $-4.7 \pm 0.4$ \\
\hline Grimy Gulch & $56 \mathrm{~m}(\mathrm{SPB})$ & Paleocene & Fort Union & 63 & $\leq 5$ & $120^{\mathrm{e}}$ & n.d. & $361 \pm 42$ & $-5.5 \pm 0.4$ \\
\hline
\end{tabular}

${ }^{a}$ ECS, Elk Creek Section; CIE, Paleocene-Eocene Thermal Maximum Carbon Isotope Excursion; WPB, West Polecat Bench; SPB, Southeast Polecat Bench; ${ }^{b}$ paleovegetation estimated from previous floral studies in the Bighorn Basin (see Diefendorf et al., 2014); ${ }^{\mathrm{C}}$ Mean annual precipitation (MAP) estimates from leafarea analysis of previously collected leaf specimens and their associated errors (Diefendorf, 2010; Currano et al., 2008; 2010); ${ }^{\mathrm{d}}$ MAP values for WCS7 and Honeycombs were approximated with samples collected from the Latest Paleocene site and Grimy Gulch samples were approximated with values from the Belt Ash. Although sample collections precluded leaf-area calculations (insufficient plant species), sample lithology and flora are consistent with a wet depositional environment; ${ }^{\mathrm{C}}$ Mean annual temperature (MAT) estimates (Wing et al., 2000; Currano, 2008; Currano et al., 2008); ${ }^{\mathrm{f}}$ Atmospheric carbon dioxide concentrations and standard deviations from Beerling and Royer (2011) and averaged for a 3 Ma time step for consistency with $\delta^{13} \mathrm{C}_{\text {atm }}$ values; ${ }^{\mathrm{g}}$ Carbon isotope values of atmospheric carbon dioxide as determined from benthic foraminifera and averaged using a 3 Ma time step (Tipple et al., 2010). 
Table 2. Bulk carbon isotopes and weight percent total organic carbon by stratigraphic bed.

\begin{tabular}{|c|c|c|c|c|c|c|c|c|c|}
\hline \multirow{5}{*}{$\begin{array}{c}\text { Bed name } \\
\begin{array}{c}\text { Fifteenmile } \\
\text { Creek }\end{array}\end{array}$} & \multirow{5}{*}{$\begin{array}{c}\text { Age (Ma) } \\
52.98\end{array}$} & \multirow[b]{3}{*}{ Lithology } & \multicolumn{5}{|c|}{ Position along stratigraphic level } & \multirow{4}{*}{$\begin{array}{c}\begin{array}{c}\boldsymbol{\delta}^{13} \mathbf{C}_{\text {TOC }} \\
\text { mean }\end{array} \\
-27.8\end{array}$} & \multirow{4}{*}{$\begin{array}{r}1 \sigma \\
0.3\end{array}$} \\
\hline & & & \multirow[t]{2}{*}{1} & \multirow[t]{2}{*}{2} & 3 & 4 & \multirow[t]{2}{*}{5} & & \\
\hline & & & & & $\%$ VPDB (V & t. \% TOC) & & & \\
\hline & & $\begin{array}{l}\text { Lignitic shale/clayey } \\
\text { mudstone }\end{array}$ & $-28.1(1.9)$ & $-27.5(17.2)$ & $-27.4(25.0)$ & $-27.8(46.0)$ & $-28.2(14.8)$ & & \\
\hline & & Clayey mudstone & $-26.8(8.5)$ & $-28.0(1.7)$ & $-27.5(2.9)$ & $-27.9(2.9)$ & $-27.7(12.1)$ & -27.6 & 0.4 \\
\hline \multirow{2}{*}{$\begin{array}{c}\text { Dorsey Creek } \\
\text { Fence }\end{array}$} & \multirow{2}{*}{54.37} & Carb. shale & $-26.8(20.3)$ & $-26.1(47.1)$ & $-26.4(7.6)$ & $-26.8(1.9)$ & $-26.3(4.9)$ & -26.5 & 0.3 \\
\hline & & Clayey mudstone & $-25.7(0.1)$ & $-25.3(0.1)$ & $-26.5(0.5)$ & $-25.3(0.2)$ & $-25.5(0.1)$ & -25.7 & 0.5 \\
\hline \multirow{2}{*}{ WCS7 } & \multirow{2}{*}{55.34} & Carb. shale & $-26.5(0.6)$ & $-26.5(0.8)$ & $-27.0(0.8)$ & $-26.5(0.7)$ & $-26.9(0.9)$ & -26.7 & 0.3 \\
\hline & & Mudstone & $-26.2(2.4)$ & $-26.8(1.0)$ & $-26.6(0.6)$ & $-26.7(0.7)$ & $-27.3(1.1)$ & -26.7 & 0.4 \\
\hline $\begin{array}{c}\text { Latest } \\
\text { Paleocene }\end{array}$ & 56.04 & Silt/sandstone & $-26.6(0.6)$ & $-25.7(0.6)$ & $-26.2(0.9)$ & $-26.1(1.0)$ & $-25.9(0.9)$ & -26.1 & 0.3 \\
\hline Honeycombs & 56.1 & Clayey mud/siltstone & $-25.9(16.9)$ & $-25.6(0.9)$ & $-26.9(1.1)$ & $-27.7(1.4)$ & $-27(26.1)$ & -26.6 & 0.9 \\
\hline \multirow{2}{*}{ Cf- 1} & \multirow{2}{*}{57.39} & Carb. mudstone/shale & $-25.6(2.1)$ & $-25.5(2.5)$ & $-25.3(1.8)$ & $-25.2(3.5)$ & $-25.5(3.4)$ & -25.4 & 0.2 \\
\hline & & Lignitic shale & $-26.2(49.3)$ & $-25.4(44)$ & $-26.0(38.3)$ & $-23.5(55.6)$ & $-26.0(29.9)$ & -25.4 & 1.1 \\
\hline \multirow{3}{*}{ Belt Ash } & \multirow{3}{*}{59.39} & Carb. mudstone/shale & $-25.1(3.9)$ & $-25.8(3.0)$ & $-24.6(2.0)$ & $-25.5(1.2)$ & $-25.0(1.6)$ & -25.2 & 0.5 \\
\hline & & Lignitic shale & $-25.9(14.3)$ & $-26.2(23.0)$ & $-24.4(28.9)$ & $-26.3(35.5)$ & $-25.8(30.1)$ & -25.7 & 0.8 \\
\hline & & Carb. mudstone/shale & $-24.8(3.1)$ & $-24.8(7.7)$ & $-24.9(3.4)$ & $-25.2(0.8)$ & $-25.2(4.4)$ & -25.0 & 0.2 \\
\hline \multirow[t]{2}{*}{ Grimy Gulch } & \multirow[t]{2}{*}{63} & Lignite & $-25.7(54.6)$ & $-24.8(48.2)$ & $-25.5(54.3)$ & $-25.2(55.9)$ & $-24.9(47.4)$ & -25.2 & 0.4 \\
\hline & & Carb. Mudstone & $-24.7(1.2)$ & $-25.1(3.1)$ & $-24.8(3.3)$ & $-25.4(1.5)$ & $-24.8(2.5)$ & -25.0 & 0.3 \\
\hline
\end{tabular}


Table 3. Measured bulk and compound-specific $n$-alkane, diterpenoid, and triterpenoid carbon isotope values by stratigraphic bed.

\begin{tabular}{lcccccccccccccccc}
\hline Bed name & Age $(\mathbf{M a})$ & $\boldsymbol{\delta}^{\mathbf{1 3}} \mathbf{C}_{\mathbf{T O C}}$ & $\mathbf{1 \sigma}$ & $\mathbf{N}$ & $\boldsymbol{\delta}^{\mathbf{1 3}} \mathbf{C} \boldsymbol{n}-\mathbf{C}_{\mathbf{2 9}}$ & $\mathbf{1 \sigma}$ & $\mathbf{N}$ & $\boldsymbol{\delta}^{\mathbf{1 3}} \mathbf{C} \boldsymbol{n}-\mathbf{C}_{\mathbf{3 1}}$ & $\mathbf{1 \sigma}$ & $\mathbf{N}$ & $\boldsymbol{\delta}^{\mathbf{1 3}} \mathbf{C} \mathbf{d i}$. & $\mathbf{1 \sigma}$ & $\mathbf{N}$ & $\boldsymbol{\delta}^{\mathbf{1 3}} \mathbf{C}$ tri. & $\mathbf{1 \sigma}$ & $\mathbf{N}$ \\
\hline Fifteenmile Creek & 52.98 & -27.7 & 0.4 & 10 & -31.5 & 0.5 & 10 & -31.9 & 0.8 & 10 & -25.3 & 0.7 & 7 & -27.6 & 1.0 & 8 \\
Dorsey Creek Fence & 54.37 & -26.1 & 0.6 & 10 & -30.4 & 0.5 & 3 & -31.3 & 0.1 & 2 & -23.4 & na & 1 & -26.5 & na & 1 \\
WCS7 & 55.34 & -26.7 & 0.3 & 10 & -31.0 & 0.3 & 4 & -31.4 & 0.4 & 4 & na & na & 0 & na & na & 0 \\
Latest Paleocene & 56.04 & -26.1 & 0.3 & 5 & -30.7 & 0.6 & 5 & -31.1 & 0.8 & 5 & -29.7 & 0.3 & 3 & -26.1 & 0.1 & 4 \\
Honeycombs & 56.1 & -26.6 & 0.9 & 5 & -31.6 & 0.7 & 5 & -31.9 & 1.0 & 5 & -24.6 & 1.9 & 3 & -27.0 & 1.1 & 4 \\
Cf-1 & 57.39 & -25.4 & 0.8 & 10 & -30.8 & 0.9 & 4 & -30.8 & 1.5 & 4 & -24.7 & 1.1 & 3 & -27.0 & na & 1 \\
Belt Ash & 59.39 & -25.4 & 0.7 & 10 & -30.3 & 1.0 & 4 & -31.0 & 0.6 & 4 & -23.7 & 1.8 & 4 & -27.4 & 0.4 & 2 \\
Grimy Gulch & 63 & -25.1 & 0.3 & 15 & -31.7 & 1.0 & 7 & -32.1 & 1.1 & 7 & -25.1 & 0.8 & 4 & -26.9 & na & 1 \\
\hline
\end{tabular}


Table 4. Calculated leaf $\delta^{13} \mathrm{C}$ values for $n$-alkanes, diterpenoids, and triterpenoids by stratigraphic bed.

\begin{tabular}{|c|c|c|c|c|c|}
\hline \multirow[b]{2}{*}{ Bed name } & \multirow[b]{2}{*}{ Age (Ma) } & \multicolumn{3}{|c|}{ Angiosperms } & \multirow{2}{*}{$\begin{array}{c}\text { Conifers } \\
\delta^{13} C_{\text {leaf (diterpenoids) }}\end{array}$} \\
\hline & & $\delta^{13} \mathbf{C}_{\text {leaf }(n-\mathrm{C} 29)}$ & $\delta^{13} \mathbf{C}_{\text {leaf }(n-\mathrm{C} 31)}$ & $\delta^{13} C_{\text {leaf (triterpenoids) }}$ & \\
\hline Fifteenmile Creek & 52.98 & -27.0 & -27.1 & -27.2 & -24.8 \\
\hline Dorsey Creek Fence & 54.37 & -26.0 & -26.4 & -26.1 & -22.8 \\
\hline WCS7 & 55.34 & -26.5 & -26.6 & n.a. & n.a. \\
\hline Latest Paleocene & 56.04 & -26.3 & -26.2 & -25.8 & -29.1 \\
\hline Honeycombs & 56.1 & -27.2 & -27 & -26.7 & -24 \\
\hline Cf-1 & 57.39 & -26.3 & -25.9 & -26.6 & -24.1 \\
\hline Belt Ash & 59.39 & -25.8 & -26.1 & -27 & -23.1 \\
\hline Grimy Gulch & 63 & -27.2 & -27.3 & -26.5 & -24.5 \\
\hline
\end{tabular}


Table 5. $\Delta_{\text {leaf }}$ values calculated and modeled from $n$-alkanes, diterpenoids, and triterpenoids for each stratigraphic bed.

\begin{tabular}{|c|c|c|c|c|c|c|c|c|c|c|c|c|c|c|c|}
\hline \multirow[b]{3}{*}{ Bed name } & \multirow[b]{3}{*}{$\begin{array}{c}\text { Age } \\
\text { (Ma) }\end{array}$} & \multicolumn{10}{|c|}{ Angiosperms } & \multicolumn{4}{|c|}{ Conifers } \\
\hline & & \multirow[b]{2}{*}{$\Delta_{\text {leaf }(n-\mathrm{C} 29)}$} & \multicolumn{3}{|c|}{ Calculated $^{\mathrm{a}}$} & \multirow[b]{2}{*}{$\underset{\text { (triterpenoids) }}{\Delta_{\text {leaf }}}$} & \multirow[b]{2}{*}{$1 \sigma$} & \multicolumn{4}{|c|}{ Modeled } & \multicolumn{2}{|c|}{ Calculated } & \multirow{2}{*}{\multicolumn{2}{|c|}{$\begin{array}{l}\text { Modeled } \\
\Delta_{\text {leaf- }}\end{array}$}} \\
\hline & & & $1 \sigma$ & $\Delta_{\text {leaf }(n-\mathrm{C} 31)}$ & $1 \sigma$ & & & $\begin{array}{l}\Delta_{\text {leaf- }} \\
\text { MAP }\end{array}$ & $1 \sigma$ & $\begin{array}{c}\Delta_{\text {leaf }} \\
p \mathrm{CO} 2\end{array}$ & $1 \sigma$ & $\Delta_{\text {leaf }} \mathrm{Di}$ & $1 \sigma$ & & $1 \sigma$ \\
\hline Fifteenmile Creek & 52.98 & 21.8 & 2.3 & 21.9 & 2.4 & 22.0 & 1.6 & 21.2 & 1.9 & 24.8 & 3.9 & 19.5 & 2.0 & 19.6 & 3.5 \\
\hline Dorsey Creek Fence & 54.37 & 21.2 & 2.3 & 21.7 & 2.3 & 21.3 & na & 21.4 & 1.9 & 22.1 & 2.6 & 17.9 & na & 19.9 & 3.6 \\
\hline WCS7 & 55.34 & 22.1 & 2.3 & 22.2 & 2.3 & na & na & 21.7 & 1.9 & 21.4 & 2.7 & na & na & 20.6 & 3.6 \\
\hline Latest Paleocene & 56.04 & 22.1 & 2.4 & 22.1 & 2.5 & 21.6 & 1.3 & 21.7 & 2.0 & 21.5 & 2.8 & 25.2 & 1.9 & 20.6 & 3.5 \\
\hline Honeycombs & 56.1 & 23.1 & 2.4 & 22.9 & 2.5 & 22.6 & 1.8 & 21.7 & 1.9 & 21.5 & 2.7 & 19.8 & 2.8 & 20.6 & 3.5 \\
\hline Cf-1 & 57.39 & 22.7 & 2.4 & 22.3 & 2.8 & 23.0 & na & 21.1 & 1.9 & 22.0 & 2.5 & 20.3 & 2.2 & 19.5 & 3.5 \\
\hline Belt Ash & 59.39 & 21.6 & 2.6 & 21.9 & 2.4 & 22.9 & 1.4 & 21.2 & 1.9 & 23.0 & 0.2 & 18.8 & 2.7 & 19.7 & 3.5 \\
\hline Grimy Gulch & 63 & 22.4 & 2.5 & 22.4 & 2.6 & 21.6 & na & 21.2 & 1.9 & 21.0 & 0.6 & 19.5 & 2.1 & 19.7 & 3.5 \\
\hline
\end{tabular}

${ }^{a}$ Calculated $\Delta_{\text {leaf }}$ values were determined using the $\Delta_{\text {leaf }}$ equation (Eq. 1), after correcting lipid $\delta^{13} \mathrm{C}$ values for biosynthetic fractionation $\left(\varepsilon_{\text {lipid }}\right.$; Eq. 2; Diefendorf et al., 2011; 2012), and using $\delta^{13} \mathrm{C}_{\mathrm{CO} 2}$ values from benthic foraminifera (Tipple et al., 2010). ${ }^{b}$ Modeled $\Delta_{\text {leaf }}$ from the deciduous angiosperm predictive relationship of Diefendorf et al. (2010; Eq. 3) and MAP estimates reported in Table $1 .{ }^{\circ} \Delta_{\text {leaf }-p \mathrm{CO} 2}$ modeled from Schubert and Jahren (2012) with $p \mathrm{CO}_{2}$ values reported in Table 1. ${ }^{\mathrm{d}}$ Modeled $\Delta_{\text {leaf }}$ from the conifer predictive relationship of Diefendorf et al. (2010; Eq. 4) and MAP values reported in Table 1. Uncertainties for all calculated and modeled values were determined using the Monte Carlo method. 